\title{
Aerosol Deposition Impacts on Land and Ocean Carbon Cycles
}

\author{
Natalie M. Mahowald ${ }^{1} \cdot$ Rachel Scanza $^{1} \cdot$ Janice Brahney $^{2} \cdot$ Christine L. Goodale $^{3}$ • \\ Peter G. Hess ${ }^{4}$ - J. Keith Moore ${ }^{5}$ - Jason Neff ${ }^{6}$
}

Published online: 7 February 2017

(C) The Author(s) 2017. This article is published with open access at Springerlink.com

\begin{abstract}
Purpose of Review Atmospheric aerosol deposition is an important source of nutrients and pollution to many continental and marine ecosystems. Humans have heavily perturbed the cycles of several important aerosol species, potentially affecting terrestrial and marine carbon budgets and consequently climate. The most ecologically important aerosol elements impacted by humans are nitrogen, sulfur, iron, phosphorus, and base cations. Here, we review the latest research on the modification of the atmospheric cycles of these aerosols and their resulting effects on continental and marine ecosystems. Recent Findings Recent studies have improved our understanding of how humans have perturbed atmospheric aerosol cycles and how they may continue to evolve in the future. Research in both aquatic and terrestrial environments has highlighted the role of atmospheric deposition as a nutrient subsidy, with effects on ecosystem productivity. These studies
\end{abstract}

This article is part of the Topical Collection on Aerosols and Climate

Natalie M. Mahowald

mahowald@cornell.edu

1 Department of Earth and Atmospheric Sciences, Cornell University, Ithaca, NY, USA

2 Department of Watershed Sciences, Utah State University, Logan, UT, USA

3 Department of Ecology and Evolutionary Biology, Cornell University, Ithaca, NY, USA

4 Department of Biological and Environmental Engineering, Cornell University, Ithaca, NY, USA

5 Department of Earth System Sciences, University of California-Irvine, Irvine, CA, USA

6 Environmental Studies Program, University of Colorado at Boulder, Boulder, CO, USA further emphasize the importance of local biogeochemical conditions and biota species composition to the regional responses to aerosol deposition.

Summary The size of the impact of anthropogenic aerosol deposition on the carbon cycle and the resulting climate forcing is at present not well understood. It is estimated that increases in nutrient subsidies from atmospheric deposition across all ecosystems are causing an increase in carbon dioxide uptake between 0.2 and $1.5 \mathrm{PgC} /$ year. As aerosol emissions from industrial sources are reduced to improve air quality, these enhancements in carbon uptake may be reduced in the future leading to reduced carbon dioxide emission offsets. However, large uncertainties remain, not only because of limited information on how humans have modified and will modify aerosol emissions, but also because of a lack of quantitative understanding of how aerosol deposition impacts carbon cycling in many ecosystems.

Keywords Aerosols $\cdot$ Biogeochemistry $\cdot$ Nutrients $\cdot$ Carbon cycle

\section{Introduction}

Atmospheric aerosols are liquids or solids suspended in the atmosphere. Aerosols are a significant contributor to air pollution, modify shortwave and longwave radiative fluxes, and impact cloud properties [1]. In addition to the atmospheric impacts, aerosol deposition onto land or ocean surfaces can impact various biogeochemical cycles acting as either a source of nutrients or pollutants. [2-6, $7 \bullet \bullet$. Anthropogenic activities are currently modifying the concentration and chemical composition of aerosols and thus influencing ecosystem biogeochemistry upon deposition [8]. Presently, 50\% of anthropogenic carbon dioxide emissions are taken up by the land and 
ocean [9]; the future ability of the biosphere to continue acting as a sink for carbon is uncertain and may be in part dependent on the amount and composition of aerosol deposition [10]. A recent study estimated that aerosol impacts on biogeochemistry may contribute as much climate forcing as either the aerosol direct or indirect-cloud radiative effect [9].

Aerosol deposition can be beneficial or detrimental to ecological processes depending on both the amount and composition of deposition and the underlying ecosystem conditions (e.g., soil properties), and thus the impact from aerosol deposition requires knowledge of local conditions [2, 3]. Similarly, as discussed further below, spatial patterns and temporal trends of atmospheric deposition vary greatly, and have a range of impacts on receiving ecosystems. Aerosol deposition of nitrogen (N) and phosphorus (P) on land can stimulate growth in nutrient-limited regions $[11,12]$ and the deposition of acid-neutralizing minerals can add alkalinity and base cations such as calcium $\left(\mathrm{Ca}^{2+}\right)$ to depositional regions $[13,14]$. In contrast, the deposition of acidic species such as sulfate or nitrate can reduce soil $\mathrm{pH}$ and alter cation exchange capacity thereby reducing the availability of required cations such as $\mathrm{Ca}^{2+}$ [2]. Nitrogen limitation is thought to be widespread in terrestrial systems [15], while tropical forests and savannahs may be phosphorus or base cation limited [16, 17], and nutrient colimitation is common in both terrestrial, marine, and freshwater aquatic ecosystems [18]. Anthropogenic deposition of $\mathrm{N}$ or $\mathrm{P}$ to these regions may enhance carbon uptake [3, 11, 12, 19]. Freshwater aquatic systems are likely to be sensitive to both $\mathrm{N}$ and $\mathrm{P}$ deposition as well as to deposition of heavy metals, acidic, or acidneutralizing compounds [20-22, 23••, 24]. Productivity in some marine ecosystems can be limited by phosphorus, nitrogen, or iron [25-28], and will likely respond to enhanced anthropogenic deposition of these nutrients [5, 6]. However, anthropogenic aerosol deposition of certain metals or acidic compounds may decrease ocean productivity [29, 30].

Here, we review the relatively new research field of investigating biogeochemical impacts from aerosol deposition to continental and marine ecosystems and their feedbacks onto climate. Because of the broad nature of this question, we focus primarily on how anthropogenic aerosols impact the carbon cycle and the corresponding climate feedback, along with how these aerosols influence ecosystems (e.g., productivity, water quality). The degree to which humans have perturbed the nitrogen and sulfur cycles and, in some regions, the iron, phosphorus, and other trace metal cycles is an area of active research. While this paper emphasizes the importance of the aerosol deposition, for sulfur and nitrogen, it is often very difficult to separate the magnitude and impact of aerosol deposition from that of gaseous forms of these chemical species.
Much of the literature reviewed below does not distinguish between the gaseous, wet, and aerosol components of $\mathrm{N}$ and $\mathrm{S}$ deposition, and thus we include them in this discussion. The first section of this paper reviews recent work dedicated to understanding the magnitude of anthropogenic perturbation to aerosol sources and deposition, as well as the importance of aerosol size and chemical state. The second part of the paper focuses on the impacts of aerosol deposition onto terrestrial, freshwater aquatic, and marine ecosystems. This new area of research seeks to investigate the combined impact of multiple constituents, for example, the impact of local conditions, varying time scales, and the differential response of biotic species to aerosol deposition. Throughout the paper, we emphasize recent work, address open questions and areas of controversy, and highlight important research questions.

\section{Aerosol Sources}

Aerosols are highly heterogeneous in space, time, and chemical composition [1]. The atmospheric aerosol mass budget is dominated by natural desert dust and sea-salt aerosols [1]. The direct radiative effects and indirect cloud effects (whereby the radiative balance is modified directly by aerosols or indirectly through modifying cloud albedo) are mainly controlled by aerosol surface area and tend to be dominated by fine mode particles $(0.1$ to $2 \mu \mathrm{m}$ diameter). In contrast, some biogeochemically important aerosols (e.g., those containing Fe, P, base cations) have most of their mass in the coarse mode $(>2 \mu \mathrm{m})$ [31]. Common methods for determining aerosol properties, such as aerosol optical depth obtained from satellite and remote sensing approaches, readily capture the fine mode aerosols but satellite methods tend to work less well for coarse mode aerosols, and thus are not sufficient to estimate aerosolbiogeochemistry impacts $[31,32]$. The magnitude of the current atmospheric budgets for different elements considered here are quite different; as described below, the best estimates are $110 \mathrm{Tg} \mathrm{N} /$ year, 50.5 Tg S/year, and $60 \mathrm{Tg} \mathrm{Fe} /$ year, but only $1 \mathrm{Tg}$ P/year (Fig. 1). Note particularly the large N:P deposition ratio of $110: 1$, whereas the Redfield ratio is $16: 1$. Here, we are focused on the anthropogenic aerosols and their impact. There are multiple methods for identifying natural versus anthropogenic sources, including bottom-up emission estimates, [e.g. 40], as well as top-down estimates based on observed spatial distributions, correlations between elements [e.g. 45], or isotope-based discrimination [e.g., 46, 47]. The ongoing work to separate the role of natural and anthropogenic processes in contributing to aerosol fluxes and the work on characterizing chemical composition and particle size distribution of aerosols will be the focus of this section. 


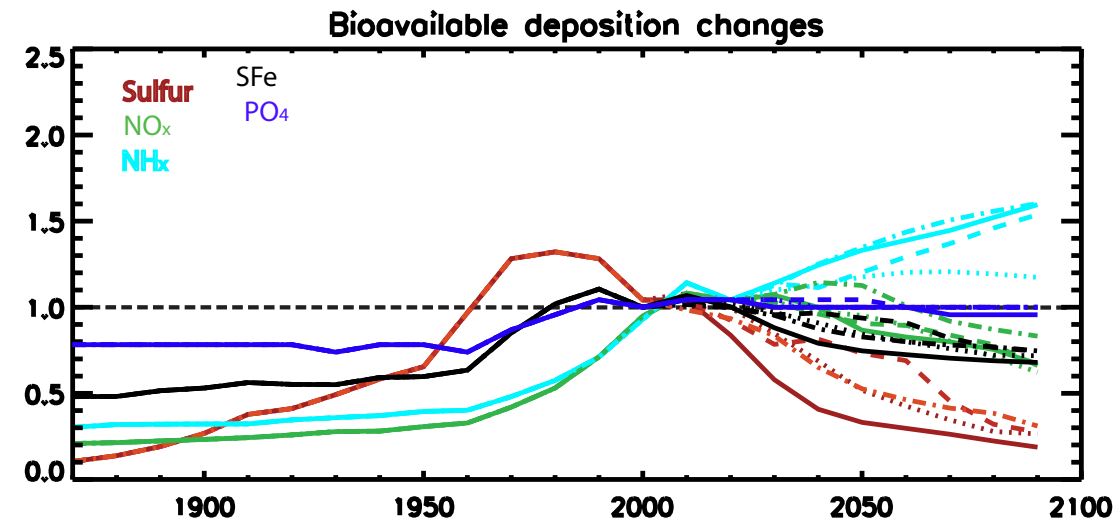

Fig. 1 Relative changes in emission changes for aerosol species relative to emissions in 2000. For the future, estimates are based on the representative concentration pathways estimates for four different scenarios [33-39], represented by the four lines into the future. Deposition changes for important species, all normalized to 2000 values (b) for sulfate (red), nitrogen oxides (green), ammonia (cyan), soluble iron (SFe) (black), and soluble phosphorus (PO4) (blue) based on historical estimates [40], and for future estimates, the representative concentration pathways [33-39]. Changes for $\mathrm{SFe}$ and $\mathrm{PO} 4$ use estimates of desert dust changes from [41], assuming in the future the model mean for no carbon dioxide fertilization changes in source area from [42], with iron solubility estimates from [43, 44], scaled by the sulfate deposition changes shown and for combustion soluble iron sources from [44] scaled by the black carbon emission changes. For soluble phosphorus (phosphates), desert dust estimate changes are the same as described for iron, and combustion sources of phosphorus come from [45], and are scaled by black carbon emissions. Adapted from [8]

\section{Nitrogen and Sulfur Aerosol Sources}

Both nitrogen and sulfur atmospheric cycles have been heavily perturbed by human activities, and their sources include both gas phase primary emissions (emitted directly into the atmosphere) and secondary aerosol formation (formed in the atmosphere from precursor gas species, e.g., $\mathrm{NO}, \mathrm{NH}_{3}$, or $\mathrm{SO}_{2}$ ) [48] (Fig. 1). Emission and deposition data for $\mathrm{N}$ and $\mathrm{S}$ constituents are included in the standard historical and future datasets created for the Climate Model Intercomparison Project (CMIP) [40, 49]. Emission and deposition estimates are critical to understanding the effects of aerosols on ecosystems because, as noted below, uncertainties in these fluxes lead to uncertainties in the assessment of impacts.

Estimates suggest that nitrogen aerosol and precursor emissions to the atmosphere have increased by approximately $250 \%$ over preindustrial conditions, with nearly half of these emissions being processed into aerosols in the atmosphere [50, 51] (Fig. 1) with much of the increase occurring near industrialized regions in the Northern Hemisphere (Fig. 2). The primary emission sources of $\mathrm{N}$ aerosols are nitrogen oxides $\left(\mathrm{NO}\right.$ and $\left.\mathrm{NO}_{2}\right)$ and ammonia $\left(\mathrm{NH}_{3}\right)$ released during fossil fuel combustion and as the result of agricultural activities including manure production and the use of fertilizers (both synthetic fertilizers and manure). Human activity is thought to have increased sulfate precursor emissions by a factor of 5 [40]. Naturally occurring sulfate aerosols are directly emitted from volcanoes while a large fraction of sulfur-bearing compounds (e.g., dimethyl sulfide and hydrogen sulfide) from ocean emissions are chemically transformed into sulfate aerosols in the atmosphere. The most significant biogeochemical impact from increased sulfur emissions is the acidification of precipitation and subsequent impacts on the receiving ecosystems.

A recent observational synthesis has characterized the global spatial distribution and the recent changes in precipitation chemistry and deposition fluxes, and includes the wet and dry, gas and aerosol deposition of sulfur, nitrogen, and phosphorus along with estimates of $\mathrm{pH}[52 \bullet \bullet]$. This work provides important constraints on ecosystem impacts; however, reliable dry deposition fluxes are difficult to measure, and these fluxes may contribute significantly to deposition budgets in many locations $[52 \bullet \bullet$. Because of the short lifetime of aerosols, paleorecords at multiple locations must be synthesized in order to obtain regional signals [53] and thus we are not able to measure paleo time series for $\mathrm{N}$ and $\mathrm{S}$ aerosol deposition except at very unique locations (e.g., [54]). Therefore, for most regions, we must rely on estimates of emissions and models to estimate the magnitude of deposition changes in the past.

Global emissions of sulfur dioxide, nitrogen oxides, and ammonia have changed in the last several decades with strong regional variations. These changes are likely to have induced rather dramatic variations in aerosol composition and deposition, especially in regions close to industrial or agricultural activity [52••]. Global anthropogenic sulfur emissions have generally decreased since the mid-1970s (estimated emissions in 2011 are $50 \mathrm{Tg} \mathrm{S} /$ year) but with strong regional variations in the emission trends [55] (Fig. 1). Most notably, Asian emissions have been estimated to have peaked in 2006, while European and North American emissions have been decreasing since the mid-1970s [55]. On the other hand, global emissions of nitrogen oxides ( $\mathrm{NO}$ and $\mathrm{NO}_{2}$ ) have changed little 
Fig. 2 a Modeled ratio of current to preindustrial $\mathrm{N}$ deposition from the Community Atmospheric Model (CAM4). b Modeled ratio of current to preindustrial phosphorus deposition. c Modeled results of the current to preindustrial $\mathrm{N}: \mathrm{P}$ ratios in deposition. The hemispheric difference in the mass flux changes of $\mathrm{N}$ versus $\mathrm{P}$ is clearly shown. d Stoichiometric representation of the relative impact of $\mathrm{P}$ versus $\mathrm{N}$ displayed as a ratio of the current to preindustrial deposition rates based on results from the CAM (v4). Values are calculated as current/preindustrial in units of $\mathrm{C}$, such that $\mathrm{P}$ is represented as $\mathrm{P} \times 106$, and $\mathrm{N}$ as $\mathrm{N} \times 6.625$. Values are shown as positive (reds) when increases in $\mathrm{P}$ deposition dominate, and negative (blues) when increases in $\mathrm{N}$ dominate. Adapted from [23] a Current/preind model $\mathbf{N}$

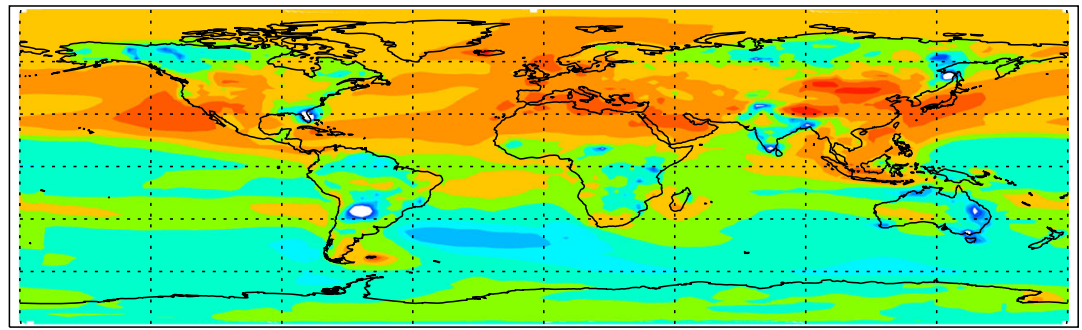

bcurrent/preind P.

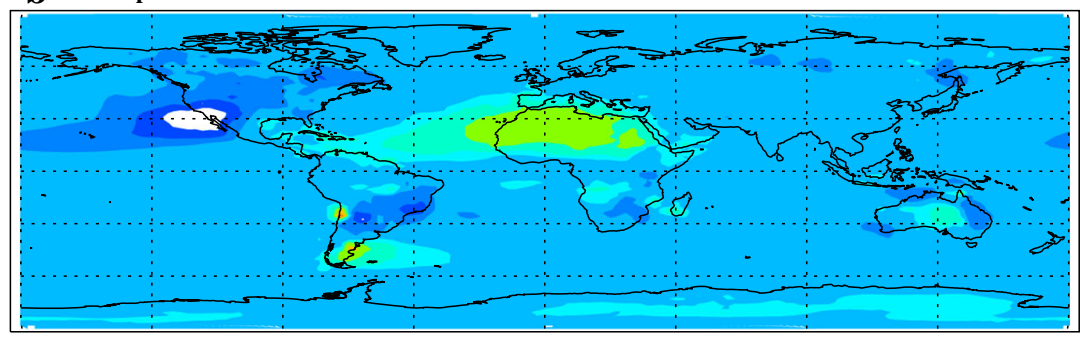

C Current/preind model N/P

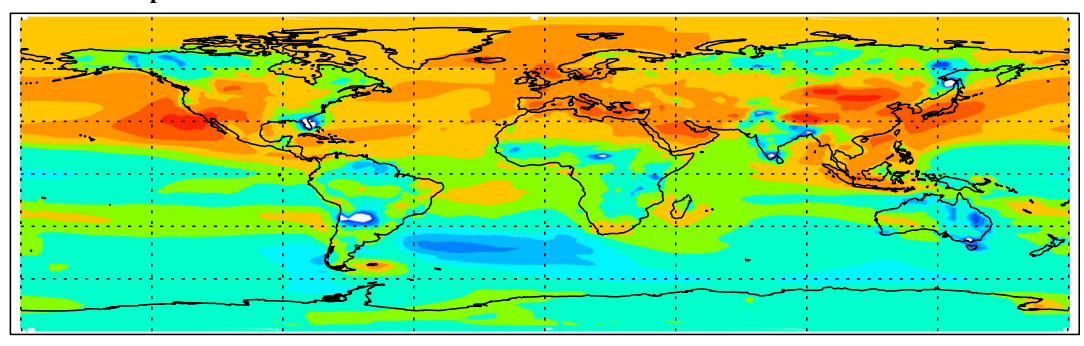

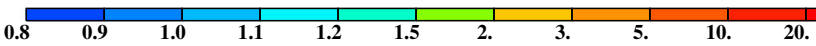

d Current/preind model $\mathrm{N} / \mathrm{P}$ in units of $\mathrm{C}$

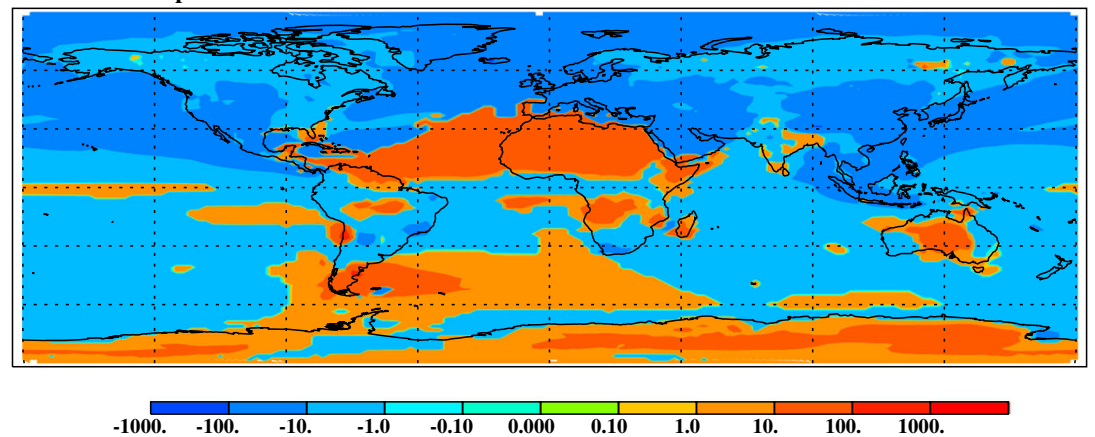

over the last decade (current emissions are $48.4 \mathrm{Tg} \mathrm{N} /$ year), but with large increases regionally in China and India offset largely by decreases in Western Europe and the USA [56, 57] (Fig. 1). Decadal trends in ammonia emissions are difficult to estimate (current estimated emissions are $58 \mathrm{Tg} \mathrm{N} /$ year) [58・•], but recent simulations suggest ammonia emissions have increased since the preindustrial era by a factor of 7 (from 3 to $21 \mathrm{Tg} \mathrm{N} /$ year) due to the increased production of manure (from 0 to $12 \mathrm{Tg} \mathrm{N} / \mathrm{year}$ ) and due to the use of synthetic fertilizer [59-61]. Current estimates of $\mathrm{N}$ and $\mathrm{S}$ emissions from fossil fuel combustion sources are relatively well characterized [59], but emission changes from soils and agricultural practices are generally harder to estimate. The latter emissions depend on the interplay among climate, land use and land use conversion, wildfire suppression [60-62], and agricultural practices. Uncertainty in nitrogen budgets may also arise from neglecting organic nitrogen species [51]. Satellite measurements have been interpreted to deduce quantitative $\mathrm{NO}$ and $\mathrm{NO}_{2}$ emission estimates [56] and $\mathrm{NO}_{2}$ tropospheric trends [63].

Globally, anthropogenic $\mathrm{NO}, \mathrm{NO}_{2}$, and $\mathrm{S}$ emissions are projected to decrease in the next century due to more stringent air pollution controls [49]. On the other hand, ammonia emissions are widely projected to increase due to increases in population and food equity, and possibly increased use of biofuels, although these drivers could be partially offset by 
increases in agricultural efficiency [64] and diet optimization (Fig. 1). Future changes in aerosol composition are thus also expected to be substantial with ammonia nitrate aerosols expected to be of increased importance [65]. While this has been hypothesized to reduce overall atmospheric acidity, one study suggests aerosol acidity will remain at current levels until atmospheric sulfate reaches near preindustrial levels [66]. Climate also impacts ammonia volatilization with recent studies estimating approximately 3-7.5\% increase in agricultural emissions of ammonia per degree Celsius warming in the future $[67,68]$. Under the representative concentration pathway (RCP) 8.5 scenario [69] for climate change and middle of the road assumptions for agricultural fertilization accounting for population change, per capita caloric intake and meat consumption a recent study predicts emissions of ammonia will double again by 2100 , with $23 \%$ of this increase attributable to climate change [70]. Understanding the climate response due to emissions from agriculture and animal management is likely to require additional field observations and modeling studies.

\section{Iron, Phosphorus, and Base Cations}

In contrast to $\mathrm{N}$ and $\mathrm{S}$ species, iron $(\mathrm{Fe})$, phosphorus $(\mathrm{P})$, and base cations occur in the atmosphere almost entirely in the aerosol phase; they are predominantly coarse mode primary aerosols such as mineral dust [43, 45, 71-77]. Because coarse mode aerosols have short lifetimes (hours to days), they are usually deposited close to the source regions, although they can sometimes travel long distances $[78,79]$. Recent studies have highlighted the importance of considering the large size fraction of primary aerosols for biogeochemistry [73, 74, 78-80], especially when comparing observed deposition to aerosol model deposition. Models and in situ concentration observations typically only includes long-range transported aerosol modes $(<10 \mu \mathrm{m})[23 \bullet \bullet, 81,82]$ as this is the size range that dominates the aerosol optical depth and are thought to be most important for health effects [83], and thus neglect the large aerosol sizes which will be dominant close to primary aerosol sources.

Iron, phosphorus, and base cations are likely to have some contribution from industrial and biomass burning combustion sources [84-87] and volcanoes. [88]. The sources of base cations such as $\mathrm{Ca}^{2+}$ to the atmospheric in interior continental regions is mostly wind-blown dust [14] whereas base cations are associated with marine aerosols in coastal and maritime settings. [89]. Because phosphorus is a required macronutrient, biota tend to accumulate phosphorus, causing primary biogenic aerosols from both ocean and land to contribute $\sim 10 \%$ of the aerosol P $[45,90,91]$. Iron, phosphorus, and other metals in aerosols are less studied than $\mathrm{N}$ and $\mathrm{S}$ aerosols, and of these, iron is the most studied. Thus, estimates for $\mathrm{Fe}, \mathrm{P}$, and base cations such as $\mathrm{Ca}^{2+}$ are not available in the standard CMIP emission and concentration datasets [40, 49] but are estimated from individual model and observational synthesis $[43,45]$, and are likely to have greater uncertainty. For example, a constant climatological iron deposition to the oceans was used in the CMIP5 studies [92] to look at ocean carbon cycling.

Because particles fall through the ocean mixed layer within a few hours to days, only the soluble or bioavailable fraction of the iron, phosphorus, or calcium may be available to the ocean biota $[5,93,94]$. The spatial distribution of different minerals and elements can be deduced from soil maps, limited soil elemental data, and from size distribution assumptions [95-100], and provide some increased ability in the simulation of fractional $\mathrm{Fe}, \mathrm{Al}$, and $\mathrm{Ca}$ in dust [101]. Previously, most studies assumed $3.5 \%$ of dust was iron with a mean dust solubility of $2 \%$ [5]; however, recent studies have highlighted the importance of the various chemical states of iron in dust minerals on the solubilization rate of iron [102-105, 106••]. Different mechanisms for solubilization of iron have been proposed, including photochemical-, acidic-, and organic ligand-mediated reactions [107-111]. Studies have also identified the potential importance of more soluble forms of iron from biomass burning, coal, and other combustion sources $[84,85,112]$, since in some regions of the globe, long-range transported combustion iron may be quite important (for example, parts of the Southern Ocean) [44, 113]. Based on local measurements $[109,110]$ metals in aerosols from mining and smelting operations may be important but are not yet included in model estimates and global budgets.

Observations suggest an inverse relationship between the amount of iron and the solubility of the iron [94, 114]. While intriguing, these observations do not uniquely constrain which processes are most important, since several hypothesis are consistent with this relationship. For example, if fine particles, with longer lifetimes, have higher solubilities (e.g., fine combustion particles versus coarse dust particles) [84, 85, 112], or if atmospheric processing takes time to solubilize aerosols [107, 108, 115], higher iron amounts will occur closer to the sources, with higher solubilities occurring farther from the sources. The emissions atmospheric iron is likely to be $\sim 60 \mathrm{Tg} \mathrm{Fe} /$ year, with soluble iron being about 1-2 Tg Fe/year [43], with large ranges possible depending on the size of the aerosol considered [116] (Fig. 1). Our understanding of the distribution and processes important for the formation of soluble iron is constrained by the very limited observations [117, $118]$, largely as daily averages over the oceans from cruises [93, 94].

The limited paleo-observations suggest a $40 \%$ increase in dust over the twentieth century, which would suggest a large increase in atmospheric iron deposited to the oceans [41, 119] (Fig. 1). This large increase in dust may in part be explained by an anthropogenic land use source, which detailed model- 
data comparisons based on satellite-retrieved aerosol distributions suggest is $25 \%$ of current dust sources [120], and/or by increased aridity associated with climate change [42]. In addition, the increase in combustion iron, as well as increased acidity $[110,111]$ from $\mathrm{S}$ and $\mathrm{N}$ emissions likely has increased the soluble iron deposition to the oceans 3-4-fold over the twentieth century [41]. Improvements in air quality in the future may reduce soluble iron deposition from combustion iron [113] although future scenarios for whether iron deposition from dust sources will increase or decrease is subject to competing processes such as increased dust due to land use change [121, 122] or increased aridity [42, 123], decreased dust due to wind changes [124], or some combination of these processes (Fig. 1).

Phosphorus sources and concentrations have received less attention than N, S, and even less than Fe from the atmospheric community [52••]. A recent synthesis of limited available observations and modeling focused on long-range transportation was able to simulate the fine and coarse mode aerosols $(<10 \mu \mathrm{m})$, as well as the observed source apportionment, based on emission factors from the literature [45]. More recent compilations of deposition fluxes in terrestrial and fresh water ecosystems show the enhanced deposition associated with local sources of primary biogenic aerosols [23••, 125]. Models can make simple assumptions for the sources of super-coarse mode ( $>10 \mu \mathrm{m}$ diameter) aerosols in terrestrial ecosystems that are consistent with the few studies of primary biogenic particles [90, 126-128], allowing model simulations to match observations for fine, coarse, and super-coarse mode, the latter of which dominates the deposition close to the source regions $[23 \bullet \bullet, 125]$. Differences in the details of how size distributions are considered can result in very large differences in the estimates from different sources (contrast the 20-fold higher combustion P estimate from [129] compared with [23••, 125]) highlighting the sensitivity of the $\mathrm{P}$ budget to assumptions in the size distributions of $\mathrm{P}$ aerosols, especially when comparing to deposition data in primary aerosol source regions.

Similar to Fe, not all $\mathrm{P}$ is equally available to aquatic biota, and there is even less solubility data for phosphorus in either marine or lacustrine systems [45, 130]. The limited data suggests a difference in source solubility, with mineral dust sources being more insoluble than other sources [45]. Recent observational data suggest phosphorus undergoes atmospheric processing to make it more soluble as it moves downwind [130], with acidic processing hypothesized to be the dominant mechanism [131, 132]. The total atmospheric phosphorus in the fine and coarse modes $(<10 \mu \mathrm{m})$, emitted in aerosol form is likely to be about $1 \mathrm{Tg} \mathrm{P} /$ year, and only $0.25 \mathrm{Tg} \mathrm{P} /$ year is likely to be soluble [45], with large ranges possible if different sizes are considered [116, 125, 129].

Because of the link between $\mathrm{P}$ and mineral aerosols, $\mathrm{P}$ deposition is likely to have increased with the increased sources of dust over the twentieth century [41]. Acidification through anthropogenic emissions is also likely to have directly enhanced the solubility of $\mathrm{P}$ [132], in addition to the increase in direct emissions of anthropogenic combustion $\mathrm{P}$ [8] (Fig. 1), with a distinct spatial signal than increases in $\mathrm{N}$ deposition, thus impacting N:P ratios in deposition (Fig. 2). To better understand atmospheric deposition of soluble iron and phosphorus, additional field and laboratory studies in cooperation with modeling studies are required.

Human activity has likely perturbed base cations and other aerosol metals (e.g., $\mathrm{Ca}, \mathrm{Cu}, \mathrm{Mn}$ ). While some of these trace metals may serve as nutrients, others may act as pollutants in terrestrial and aquatic ecosystems [30, 133]. The amount of change in deposition of such trace metals from aerosol, as well as their significance on the carbon cycle, has not yet been established.

\section{Aerosol Deposition Impacts on Ecosystems}

The study of the impact of aerosol deposition onto ecosystems began in earnest with heightened awareness of acid rain issues in the 1980s and 1990s [2], and has evolved by considering the influence of anthropogenic aerosol deposition, which can modify land, freshwater, and marine productivity [2-6, 7••, 134] and potentially significantly affect climate through the carbon cycle [10]. Recent evidence has highlighted the necessity of considering ecosystem impacts as a combination of the strong spatial gradients in aerosol deposition, local conditions, different time scales, multi-element interactions with carbon, and the varied impacts on different biotic species, which will be the themes of this section.

\section{Terrestrial Ecosystems}

Nitrogen limitation is thought to be widespread in many systems, especially temperate forests [15], and thus the large increase in anthropogenic deposition of $\mathrm{N}$ may enhance carbon uptake, but the magnitude of this $\mathrm{N}$-induced $\mathrm{C}$ sink has been contentious $[3,11,12,19,135]$. $\mathrm{N}$ impacts are the most well studied of all the deposition-driven terrestrial carbon feedbacks, and some earth system models include some of the relevant $\mathrm{N}$ cycling processes [136]. Recent model estimates suggest between 0.24 and $0.7 \mathrm{Pg}$ of carbon $(\mathrm{PgC}) /$ year are taken up by terrestrial ecosystems due to anthropogenic nitrogen deposition effects on plant growth [3, 11, 137]. None of these models simulate the effects of $\mathrm{N}$ addition in suppressing soil decomposition rates. In temperate and boreal forests, this effect can yield increases in soil $\mathrm{C}$ storage as large as the effects of $\mathrm{N}$ on tree $\mathrm{C}$ gain $[138 \bullet \bullet, 139,140]$. Nitrogen deposition not only affects $\mathrm{C}$ storage, but can also contribute to ecosystem emissions of nitrous oxide and nitric oxide and can suppress the uptake of atmospheric methane in surface 
soils [141-143]. Nitrogen can act as both a nutrient and a pollutant depending on the amount of deposition and plant and soil conditions [2, 3].

Acid rain, in contrast, which predominately comes from the deposition of sulfate and some forms of nitrogen, can reduce the availability of required base cations such as $\mathrm{Ca}^{2+}$ and reduce productivity in forest ecosystems that lack sufficient buffering $[2,144]$. For forests growing on calcium-poor sites, high loads of acid deposition can reduce soil calcium availability and cause a slowdown in growth and increase mortality [145]. Chronic acidification can also increase soil $\mathrm{C}$ storage by slowing decomposition, a process reversed when ecosystems recover from reductions in acid deposition [146]. As acid deposition has decreased across northern Europe and eastern North America, losses of dissolved organic carbon (DOC) from soils to streamwater have increased, likely due to increased dissolved organic carbon solubility at higher $\mathrm{pH}$ [147]. This deacidification-driven change in DOC loss generally has a small effect on terrestrial carbon balance but can substantially alter the DOC inputs to aquatic ecosystems [e.g., [148]. Overall, the net global carbon impact of acid rain onto changes in greenhouse gas emissions has yet to be established, and regional responses will vary with the direction and magnitude of changes in acidic deposition and loading, as discussed in the emission section. Deposition of sulfate onto peatlands can suppress their emissions of methane, although the net global effect on methane budgets is not thought to be large [149].

Certain bedrock and ecosystem types (e.g., tropical forests and savannahs) can lead to phosphorus limitation and low base-cation availability $[16,17,150]$. On long time scales, atmospheric aerosols, especially dust, may provide essential nutrients [151]. Studies have shown that North African dust is a source of $\mathrm{P}, \mathrm{Fe}$, and base cations to the heavily weathered tropical soils of the Amazon. These inputs provide nutrients and potentially enhance productivity over long time scales $[12,152]$ and may be essential to the long-term survival of these ecosystems [153]. Similarly, Hawaiian forests have been shown to be dependent on atmospheric inputs of base cations [154], and alpine forests in Europe derive substantial portions of their base-cation subsidies for growth from dust [155]. Recent studies have shown substantial perturbations to atmospheric phosphorus in the Amazon due to deforestationrelated biomass burning [19] and land use [156] suggesting that anthropogenic phosphorus deposition in the Amazon may be enhancing productivity (i.e., net primary production) in the remaining forests, by between 0 and $0.5 \mathrm{PgC} /$ year [10]. Modeling studies of the influence of phosphorus deposition onto carbon uptake are in the beginning stages [157, 158]; based on ecosystem budgets, they suggest a smaller role for phosphorus deposition than for nitrogen deposition [157, 158].
Overall, it is clear that nutrient-rich aerosols play an important role in the growth of forests and subsequent uptake of carbon around the world, with substantial regional variations. It is, however, substantially less clear how important these fluxes are to rates of tree growth or how much human activity may have modified these impacts. In a general sense, we know that human perturbation of the $\mathrm{N}$ cycle exceeds that of any other biogeochemical cycle and therefore the $\mathrm{N}$ deposition effects on ecosystems are likely to be greater than for any other deposition flux. However, over longer timescales (e.g., centuries to millennia) even subtle shifts in deposition of $\mathrm{P}, \mathrm{Fe}$, and the base cations could have profound implications for forest development and growth. These issues of both shortand longer term impacts of aerosol deposition are important open questions deserving further research.

\section{Freshwater Aquatic Ecosystems}

Anthropogenic nitrogen deposition has long been recognized as an important modifier of freshwater ecosystems, particularly in remote oligotrophic (low-nutrient) systems. $\mathrm{N}$ deposition has been linked to acidification and shifts from N- to P limitation [21, 159]. More recent studies have focused on the role of phosphorus, specifically the potential for phosphorus deposition to increase productivity, alter species composition, and shift freshwater systems toward $\mathrm{N}$ limitation $[7 \cdot \bullet, 22,160]$. Using a strong observed correlation between the N:P of atmospheric deposition and lake water, one recent study argues that aerosol deposition is a much more important factor in controlling relative nutrient availability than previously thought $[23 \cdot \bullet$. Though humans are modifying $\mathrm{N}$ much more than $\mathrm{P}$, considering the Redfield ratio of C:N:P (106:16:1) as a measure of average biological nutrient requirements suggests that $\mathrm{P}$ deposition is likely to be more important than $\mathrm{N}$ in many ecosystems (Fig. 2).

Though atmospheric deposition of nutrients has been linked to lake eutrophication [161,162], the potential effects on the carbon budget are less clear. Increases in lake productivity can lead to increases in carbon burial rates $[163,164]$. However, lakes are sites of complex carbon processing and whether or not carbon is respired, transported, or buried within the sediments is heavily influenced by other factors including morphology, hydrology, latitude, food webs, and vertical mixing regime [165-167]. Although freshwater systems occupy only a small fraction of the landscape, their impact on the carbon cycle is significant. Although the area they cover and total carbon storage may be smaller, lake systems may be able to take up more carbon annually than marine sediments [164, 168, 169], Given the magnitude of carbon processed and sequestered in lakes, and the likely sensitivity of aquatic systems to aerosol deposition, more work is needed to understand how 
increased anthropogenic aerosol nutrient deposition may interact with climate change to affect the global carbon budget.

\section{Marine Ecosystems}

Nitrogen, phosphorus, and iron are known to limit biological productivity and carbon export in the oceans [5, 21, 129]. Thus, atmospheric deposition of these nutrients can directly impact ocean carbon fluxes, particularly where the nutrient deposited is the growth-limiting nutrient for some of the phytoplankton (Fig. 3). When a non-growth-limiting nutrient is deposited, circulation may transport it long distances before directly impacting productivity [171]. While a few studies have argued that anthropogenic nitrogen deposition is very important for ocean biogeochemistry [6, 172], most consider anthropogenic iron deposition to be the more important factor for carbon uptake [173, 174] because of iron limitation and the potential for large productivity increases in high-nutrient, lowchlorophyll (HNLC) regions of the open ocean $[25,28,106 \bullet$, 175•]. Nitrogen fixers extend this sensitivity to atmospheric iron deposition to oligotrophic ocean regions [22, 132, Fig. 3]. Smaller basins may be more sensitive to atmospheric deposition; for example, temporal trends in $\mathrm{N}$ and $\mathrm{P}$ suggest that an initial increase in nitrogen in the Mediterranean resulted in lower $\mathrm{N}$ concentration in response to higher atmospheric deposition, while the phosphorus budgets seem more driven by
Fig. 3 Nutrient limitation map displays the main growth-limiting nutrient over the annual time scale during the 1990s for different phytoplankton functional groups. Darker shade of each color indicates stronger nutrient limitation (growth reduced by $>50 \%$ from maximum). Nutrient replete means nutrient concentrations are sufficient for the phytoplankton to grow at $>90 \%$ of their maximal rates, typically indicating light and/or grazing controls on biomass. a Diatom growth limitation. b Small phytoplankton growth limitation. c Diazotroph growth limitation. Adapted from [170] using a recent simulation

\section{a Diatom Growth Limitation}

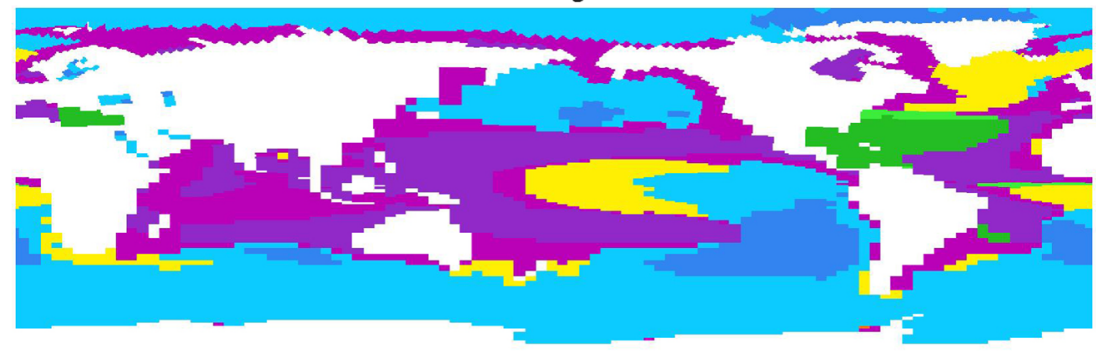

Nitrogen 43.78\%, Iron 42.31\%, Silico $9.106 \%$, Phosphorus $4.791 \%$ Replete $0.006 \%$

nNitrogen Iron IPhosphorus Silicon Temperature Replete

b Small Phytoplankton Growth Limitation

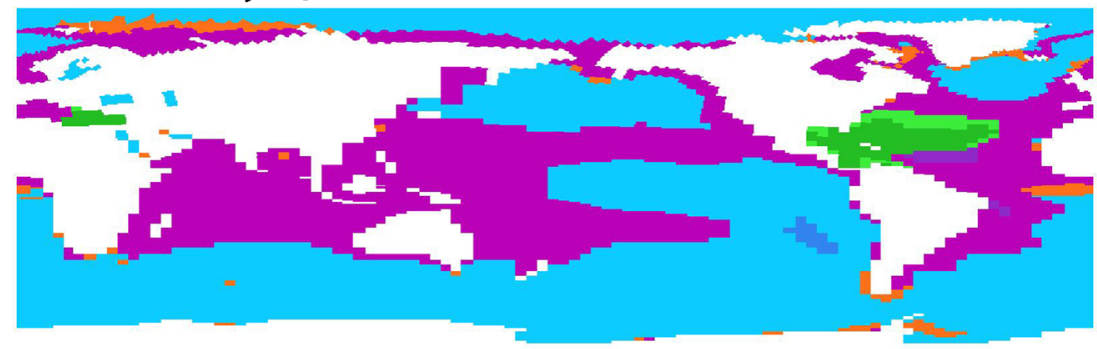

Nitrogen 45.59\%, Iron 51.49\%, Phosphorus $1.161 \%$ Replete $1.748 \%$

\section{Diazotroph Growth Limitation}

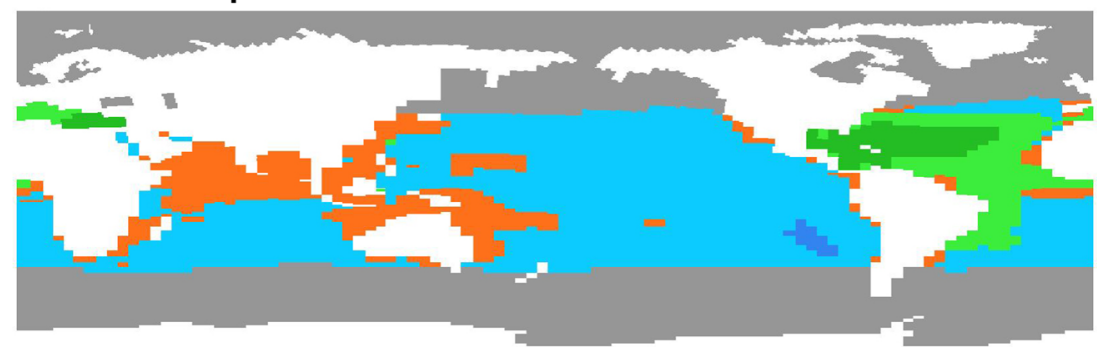

Nitrogen $0.000 \%$, Iron 43.52\%, Phosphorus $10.01 \%$ Replete $13.39 \%$, Temperature $33.06 \%$ 
the riverine inputs $[176,177]$. Atmospheric deposition often results in an oscillatory deposition and response cycle that needs to be considered in understanding short and long time scale responses, especially in low-nutrient low-chlorophyll regions [178]. The larger increases in $\mathrm{N}$ deposition than $\mathrm{P}$ in many regions of the globe (Figs. 1 and 2) can cause shifts from $\mathrm{N}$ to $\mathrm{P}$ limitation [175•]. Quantitatively linking carbon fluxes to atmospheric nutrient deposition is complicated by uncertainties in the input rates and internal cycling of each key nutrient, and by interactions and feedbacks across these biogeochemical cycles within the oceans.

Iron cycling within the oceans is less well understood than other nutrients, due to large uncertainties in the inputs of dissolved iron, scavenging losses and interactions with organic ligands, and a limited global observational dataset $[137,139,179,180 \cdot 181]$. A recent marine Fe cycle model intercomparison [180 ${ }^{\circ}$ documented orders of magnitude uncertainties in iron sources and residence time across 13 global ocean models. Observational iron-related datasets are rapidly expanding through the GO-SHIP and GEOTRACES programs, providing new insights into iron sources and sinks $[182 \bullet, 183]$. GEOTRACES measures a wide suite of trace elements, some of which may serve as micro-nutrients. Zinc is released from mineral dust deposition, and may influence the ability of phytoplankton to access dissolved organic phosphorus pools [184], illustrating an additional potential link between mineral dust deposition, phosphorus, and carbon.

Nitrogen-fixing plankton species (diazotrophs) have elevated iron requirements, and their growth may be iron-limited over large areas of the oceans, where most of the community is N-limited (Fig. 3). Nitrogen fixation rates can be sensitive to atmospheric iron inputs [22, $105,132,135]$ linking marine $\mathrm{N}, \mathrm{Fe}$, and $\mathrm{C}$ cycles. Declining biological nitrogen fixation can substantially offset increasing $\mathrm{N}$ deposition to the oceans [129, 133, 134]. Recent studies have found considerable regional variations and plasticity in plankton elemental stoichiometry $[140 \bullet, 175 \cdot 185,186]$. Thus, the stoichiometry of the nutrient deposition and the stoichiometric nutritional demands of different plankton species modify the impacts of nutrient deposition on marine carbon fluxes $[175 \bullet, 187]$. Planktonic organisms will respond differentially to the atmospheric deposition of nutrients (and toxins) impacting plankton community structure and the efficiency of carbon export [141, 170, 188, 189]. Recent estimates suggest an average of $0.07 \mathrm{PgC} /$ year $( \pm 100 \%)$ draw down due to soluble iron deposition increases over the twentieth century [41]. Combined field, laboratory, and modeling studies of the impacts of aerosol deposition onto the ocean are required to further reduce the uncertainties and better understand the future evolution of ocean biogeochemistry.

\section{Summary and Conclusions}

The impacts of aerosols especially N, S, Fe, P, and base cations on climate through terrestrial, freshwater, and marine carbon cycling may be as important as aerosol direct and aerosol-cloud impacts on radiation [10]. However, the biogeochemical processes linking aerosol deposition to carbon cycling have not been extensively investigated. Here, we review current research in this area and identify important research questions.

Though $\mathrm{N}$ and $\mathrm{S}$ sources are well studied, present and future agricultural emissions of $\mathrm{N}$ are still uncertain. For marine and aquatic ecosystems, the soluble forms of $\mathrm{Fe}$ and $\mathrm{P}$ are likely to be more important. The solubility of atmospheric forms of iron and phosphorus is likely enhanced by anthropogenic activity directly through combustion emissions, as well as through increased emissions of acidic species (e.g., sulfate and nitrate-forming compounds), but the relative role of these different processes is not well understood. For this reason, understanding the relative proportion of natural and anthropogenic emissions, and their solubility is still a priority.

Aerosol impacts on terrestrial, freshwater aquatic, and marine systems are still uncertain in terms of their carbon cycle feedbacks and thus climate. The impacts of increased anthropogenic nitrogen deposition (about half of which is thought to be aerosol form) onto land is thought to increase uptake of carbon by 0.2 to $0.7 \mathrm{PgC} /$ year $[3,11,137]$. Increased phosphorus emissions from biomass burning may be fertilizing the remaining tropical rain forests, causing an increase in carbon uptake between 0 and $0.5 \mathrm{PgC} /$ year [10]. While potentially regionally important, the magnitude of the impact of increased sulfate deposition on the carbon cycle is not clear. The increase in atmospheric soluble iron deposition to the ocean is likely to be causing an uptake of carbon between 0 and $0.6 \mathrm{PgC} /$ year [41]. The overall size of the impact of anthropogenic aerosol deposition onto the carbon cycle and resulting forcing is likely causing an increased uptake of carbon dioxide between 0.2 and $1.5 \mathrm{PgC} /$ year in the current climate. Only the impact of anthropogenic nitrogen deposition on growth is currently considered in IPCC estimates. Future changes in aerosols are likely to be large, as industrial emissions are reduced to improve air quality and how these will influence the uptake of anthropogenic carbon by ecosystems is uncertain. Better constraining the impact on the carbon cycle should be a high research priority.

In addition to the general carbon cycle responses reviewed here, recent studies have emphasized the biotic speciesspecific response to different elements, the differing time scales of responses, and the impact of combinations of elements onto the ecosystems. Further field, laboratory, and modeling studies, as well as the synthesis between these methods are required to better understand the potential feedbacks of aerosol-biogeochemistry interactions onto climate. 
Studies need to be undertaken both within fields (i.e., atmospheric chemistry and aerosols or ecosystem biogeochemical cycling) as well as integrating across fields to better constrain our understanding of this fundamental cross-media process.

Acknowledgements We acknowledge funding from DOE: DESC000006735, DE-SC0006791 and DE-SC0016362, and NSF: AGS: 1049033 and CCF-1522054.

\section{Compliance with Ethical Standards}

Conflict of Interest There are no conflicts of interest.

Open Access This article is distributed under the terms of the Creative Commons Attribution 4.0 International License (http:// creativecommons.org/licenses/by/4.0/), which permits unrestricted use, distribution, and reproduction in any medium, provided you give appropriate credit to the original author(s) and the source, provide a link to the Creative Commons license, and indicate if changes were made.

\section{References}

Papers of particular interest, published recently, have been highlighted as:

- Of importance

•- Of major importance

1. Boucher O, Randall D, Artaxo P, Bretherton C, Feingold G, Forster P, Kerminen V, Kondo Y, Liao H, Lohman U, Rasch P, Satheesh S, Sherwood S, Stevens B, Zhang X-Y. Clouds and aerosols. In: Stocker T, Qin D, Planttner G-K, et al., editors. Climate change 2013: the physical science basis, Contribution of Working Group I to the Fifth Assessment Report of the Intergovernmental Panel on Climate Change. Cambridge: Cambridge University Press; 2013.

2. Likens GE, Driscoll CT, Buso DC. Long-term effects of acid rain: response and recovery of a forest ecosystem. Science. 1996;272(5259):244-6.

3. Nadelhoffer KJ, Emmett BA, Gundersen P, Kjønaas OJ, Koopmans CJ, Schleppi P, Tietema A, Wright RF. Nitrogen deposition makes a minor contribution to carbon sequestration in temperate forests. Nature. 1999;398:145-8.

4. Schindler DW, Alexander M, Al GDG. Atmosphere-biosphere interations: toward a better understanding of the ecological consequences of fossil fuel combustion. Washington: National Academy Press; 1981.

5. Jickells T, An Z, Andersen K, Baker A, Bergametti G, Brooks N, Cao J, Boyd P, Duce R, Hunter K, Kawahata H, Kubilay N, laRoche J, Liss P, Mahowald N, Prospero J, Ridgwell A, Tegen I, Torres R. Global iron connections between dust, ocean biogeochemistry and climate. Science. 2005;308:67-71.

6. Duce R, LaRoche J, Altieri K, Arrigo K, Baker A, Capone D, Cornell S, Dentener F, Galloway J, Ganeshram R, Geider R, Jickells T, Kuypers M, Langlois R, Liss P, Liu SM, Middelburg J, Moore C, Nickovic S, Oschlies A, Pedersen T, Prospero J, Schlitzer R, Seitzinger S, Sorensen L, Uematsu M, Ulloa O, Voss M, Ward B, Zamora L. Impacts of atmospheric anthropogenic nitrogen on the open ocean. Science. 2008;320(893) doi:10.1126/science.1150369.

7.• Stoddard J, Van Sickles J, Herlihy A, Brahney J, Paulsen S, Peck D, Mitchell RF, Pollard A. Continental-scale increase in lake and stream phosphorus: are oligotrophic systems disappearing in the United States. Environ Sci Technol. 2016;50:3409-15. Analyses of several thousand water bodies showing increases in the phosphorus content of lakes and streams across the US. Increased $P$ in remote regions are likely due to atmsopheric deposition changes.

8. Mahowald N. Atmospheric biogeochemistry. In: Leemans R, editor. Ecological systems: selected entries from the encyclopedia of sustainability science and technology. New York: Springer; 2013. doi:10.1007/1978-1001-4419-0851-1003.

9. Ciais P, Sabine C, Bala G, Bopp L, Brovkin V, Canadell J, Chhabra A, DeFries RS, Galloway J, Heimann M, Jones C, LeQuere C, Myneni R, Piao S, Thornton P. Carbon and other biogeochemical cycles. In: Stocker T, Qin D, Planttner G-K, et al., editors. Climate change 2013: the physical science basis, Contribution of Working Group I to the Fifth Assessment Report of the Intergovernmental Panel on Climate Change. Cambridge: Cambridge University Press; 2013.

10. Mahowald N. Aerosol indirect effect on biogeochemistry and climate. Science. 2011;334:794-6. doi:10.1126/science.1207374.

11. Thomas RQ, Canham CD, Weathers K, Goodale C. Increased tree carbon storage in response to nitrogen deposition in the US. Nature-geoscience. 2010;3:13-7. doi:10.1038/ngeo721.

12. Swap R, Garstang M, Greco S, Talbot R, Kallberg P. Saharan dust in the Amazon Basin. Tellus. 1992;44B(2):133-49.

13. Rogora M, Mosello R, Marchetto A. Long term trends in the chemistry of atmospheric deposition in Northwestern Italy: the role of increasing Saharan dust deposition. Tellus, B. 2004;56(5):462-34.

14. Brahney J, Ballantyne A, Sievers C, Neff J. Increasing Ca2+ deposition in the western US: the role of mineral aerosols. Aeolian Res. 2013;10:77-87.

15. Wang Y-P, Houlton B. Nitrogen constraints on terrestrial carbon uptake: implications for the global carbon-climate feedback. Geophys Res Lett. 2009;36(L24403) doi:10.1029/2009 GL041009.

16. Vitousek P. Litterfall, nutrient cycling and nutrient limitations in tropical forests. Ecology. 1984;65(1):285-98.

17. Okin GS, Mladenov N, Wang L, Cassel D, Caylor KK, Ringros S, Macko SA. Spatial pattern of soil nutrients in two southern African savannas. J Geophys Res. 2008;111(G02011) doi:10.1029/2007JG000584.

18. Elser J, Bracken M, Cleland E, Gruner D, Harpole WS, Hillebrand H, Ngai J, Seabloom EW, Shurin JB, Smith JE. Global analysis of nitrogen and phosphorus limitation of primary producers in freshwaster, marine and terrestrial ecosystems. Ecol Lett. 2007:10:1135-42.

19. Mahowald N, Artaxo P, Baker A, Jickells T, Okin G, Randerson J, Townsend A. Impact of biomass burning emissions and land use change on Amazonian atmospheric cycling and deposition of phosphorus. Glob Biogeochem Cycles. 2005;19(4):GB4030. doi:10.1029/2005GB002541.

20. Driscoll CT, Driscoll K, Roy K, Mitchell M. Chemical response of lakes in the Adirondack region of New York to declines in acidic deposition. Environ Sci Technol. 2003;37(10):2036-42. doi:10.1021/es020924h.

21. Elser J, Andersen T, Baron J, Bergstrom A-K, Jansson M, Kyle M, Nydick K, Steger L, Hessen D. Shifts in lake N:P stoichiometry and nutrient limitation driven by atmospheric nitrogen deposition. Science. 2009;326(835):835-7. doi:10.1126/science.1176199.

22. Camarero L, Catalan J. Atmospheric phosphorus deposition may cause lakes to revert from phosphorus limitation back to nitrogen limitation. Nature Communication. 2012;3:1118. doi:10.1038/ncomms2125.

23.• Brahney J, Mahowald N, Ballantyne A, Neff J. Is atmospheric phosphorus pollution altering global alpine lake stoichiometry? 
Glob Biogeochem Cycles. 2015;29. doi:10.1002/2015GB005137. Based on observational data, suggests that alpine lake N:P ratios are controlled by deposition, which is likely modified by humans.

24. Rai LC, Gaur JP, Kumar HD. Phycology and heavy-metal pollution. Biol Rev. 1981;56:99-151.

25. Martin J, Gordon RM, Fitzwater SE. The case for iron. Limnol Oceanogr. 1991;36:1793-802.

26. Falkowski P. Evolution of the nitrogen cycle and its influence on the biological sequestration of $\mathrm{CO} 2$ in the ocean. Nature. 1997;387:272-5.

27. Wu J, Sunda W, Boyle E, Karl D. Phosphate depletion in the western North Atlantic Ocean. Science. 2000;289:759-62.

28. Boyd P, Jickells T, Law C, Boyle E, Buesseler K, Coale K, Cullen J, de Baar H, Follows M, Harvey M, Lancelot C, Levasseur M, Owens N, Pollard R, Rivkin R, Sarmiento J, Shoemann V, Smetacek V, Takeda S, Tsuda A, Turner S, Watson A. Mesoscale iron enrichment experiments 1993-2005: synthesis and future directions. Science. 2007;315:612-7.

29. Doney S, Mahowald N, Lima I, Feeley R, Mackenzie F, Lamarque JF, Rasch P. Impact of anthropogenic atmospheric nitrogen and sulfur depositionon ocean acidification and the inorganic carbon system. PNAS. 2007;104(37): 0702214580-5. doi:10.1073/pnas.0702218104.

30. Paytan A, Mackey K, Chen Y, Lima I, Doney S, Mahowald N, Lablosa R, Post A. Toxicity of atmospheric aerosols on marine phytoplankton. PNAS. 2009;106(12):0811484601-5. doi:10.1073/pnas.0811486106.

31. Mahowald N, Ward DS, Kloster S, Flanner MG, Heald CL, Heavens NG, Hess PG, Lamarque J-F, Chuang PY. Aerosol impacts on climate and biogeochemistry. Annual Reviews of Environment and Resources. 2011;36:45-74.

32. Dulac F, Moulin C, Lambert CE, Guillard F, Poitou J, Guelle W, Quetel CR, Schneider X, Ezat U. Quantitative remote sensing of African dust transport to the Mediterranean. In: Guerzoni S, Chester R, editors. The impact of desert dust across the Mediterranean. Dordrecht: Kluwer Academic Publishers; 1996. p. 25-49.

33. vanVuuren D, MGD E, Lucas P, Eickhout B, Strengers B, Ruijven BV, Wonink S, Houdt RV. Stabilizing greenhouse gas concentrations at low levels: an assessment of reduction strategies and costs. Clim Chang. 2007;81:119-59. doi:10.1007/s10584-1000619172-10589.

34. Clarke L, Edmonds J, Jacoby H, Pitcher H, Reilly J, Richells R. Scenarios of greenhouse gas emissions and atmospheric concentrations. Sub-reprt 2.1A of Synthesis and Assessment Product 2.1 by the US Climate Change Science Pgoram and the Subcommittee on Global Change REsearch. Department of Energy, Office of Biological and Environmental Research, Washington, DC. 2007.

35. Smith SJ, Wigley T. Multi-gas forcing stabilization with the MiniCAM. Energy Journal. 2006;3:373-91.

36. Wise M, Calvin KV, Thomson A, Clarke LE, Bond-Lamberty B, Sands R, Smith SJ, Janetos AC, Edmonds JA. Implications of limiting $\mathrm{CO} 2$ concentrations for land use and energy. Science. 2009;324:1183-6.

37. Fujino J, Nair R, Kainuma M, Masui T, Matuoka Y. Multi-gas mitigation analysis on stabilzation scenarios using AIM global model. The Energy Journal Special Issue. 2006;3:343-54.

38. Hijoka Y, Matuoka Y, Hisimoto H, Masui M, Kainuma M. Global GHG emission scenarios under GHG concentration stabilization targets. Global Environmental Engineering. 2008;13:97-108.

39. Riahl K, Gruebler A, Nakicenovic N. Scenarios of long-term socio-economic and environmental development under climate stabilization. Technol Forecast Soc Chang. 2007;74(7):887-935.

40. Lamarque J-F, Bond T, Eyring V, Granier C, Heil A, Klimont Z, Lee D, Liousse C, Mieville A, Owen B, Schulz M, Schindell D,
Smith S, Stehfest E, VanAardenne J, Cooper O, Kainuma M, Mahowald N, McConnell J, Naik V, Riahi K, Van Vuurent D. Historical (1850-200) gridded anthropogenic and biomass burning emissions of reactive gases and aerosols: methodology and application. Atmos Chem Phys. 2010;10(7017):7017-39.

41. Mahowald N, Kloster S, Engelstaedter S, Moore JK, Mukhopadhyay S, McConnell JR, Albani S, Doney S, Bhattacharya A, Curran M, Flanner M, Hoffman F, Lawrence D, Lindsay K, Mayewski P, Neff J, Rothenberg D, Thomas E, Thornton P, Zender C. Observed 20th century desert dust variability: impact on climate and biogeochemistry. Atmos Chem Phys. 2010;10:10875-93. doi:10.5194/acp-10-10875-2010.

42. Mahowald N. Anthropocence changes in desert area: sensitivity to climate model predictions. Geophys Res Lett. 2007;34(L18817) doi:10.1029/2007GL030472.

43. Mahowald N, Engelstaedter S, Luo C, Sealy A, Artaxo P, BenitezNelson C, Bonnet S, Chen Y, Chuang PY, Cohen DD, Dulac F, Herut B, Johansen AM, Kubilay N, Losno R, Maenhaut W, Paytan A, Prospero JM, Shank LM, Siefert RL. Atmospheric iron deposition: global distribution, variability and human perturbations. Annual Reviews of Marine Sciences. 2009;1:245-78. doi:10.1146/annurev/marine.010908.163727.

44. Luo C, Mahowald N, Bond T, Chuang PY, Artaxo P, Siefert R, Chen Y, Schauer J. Combustion iron distribution and deposition. Glob Biogeochem Cycles. 2008;22(GB1012) doi:10.1029/2007 GB002964.

45. Mahowald N, Jickells TD, Alex R, Baker PA, Benitez-Nelson CR, Bergametti G, Bond TC, Chen Y, Cohen DD, Herut B, Kubilay N, Losno R, Luo C, Maenhaut W, McGee KA, Okin GS, Siefert RL, Tsukuda S. The global distribution of atmospheric phosphorus deposition and anthropogenic impacts. Glob Biogeochem Cycles. 2008;22(GB4026) doi:10.1029/2008GB003240.

46. Hastings M, Sigman DM, Lipschultz F. Isotopic evidence for source changes of nitrate in rain at Bermuda. J Geophys Res. 2003;D24(4790) doi:10.1029/2003JD003789.

47. Han X, Guo Q, Liu C, Fu P, Straus H, Yang J, Hu J, Wei L, Ren H, Peters M, Wei R, Tian L. Using stable isotopes to trace sources and formation processes of sulfate aerosols from Beijing, China. Scientific Reports. 2016;6:29958. doi:10.1038/srep29948.

48. Schlesinger W. Biogeochemistry: an analysis of global change. 2nd ed. San Diego: Academic Press; 1997. p. 588.

49. Lamarque JF, Kyle GP, Meinshausen M, Riahi K, Smith S, van Vuuren DP, Conley A, Vitt F. Global and regional evolution of short-lived radiatively-active gases and aerosols in the representative concentration pathways. Clim Chang. 2011;109:191-212.

50. Feng Y, Penner J. Global modeling of nitrate and ammonium: interaction of aerosols and tropospheric chemistry. J Geophys Res. 2007;112(D01304) doi:10.1029/2005JD006404.

51. Kanakidou M, Myriokefalitakis S, Daskalakis N, Fanourgakis G, Nenes A, Baker A, Tsigardis K, Mihalopoulos N. Past, present and future atmospheric nitrogen deposition. Journal of Atmospheric Science. 2016;73:2039-47. doi:10.1175/JAS-D-2015-0278.2031.

52.• Vet R, Artz RS, Carou S, Shaw M, Ro C-U, Aas W, Baker A, Bowersox VC, Dentener F, Galy-Lacaux C, Hou A, Pienaar JJ, Gillett R, Forti MC, Gromov S, Hara H, Khodzher T, Mahowald NM, Nickovic S, Rao PSP, Reid NW. A global assessment of precipitation chemistry and depositoin of sulfur, nitrogen, sea salt, base cations, organic acids, acidity and $\mathrm{pH}$ and phosphorus. Atmospheric Enviroment. 2014;93:3-100. Thorough compilation, review and synthesis of available data regarding precipitation chemistry and deposition.

53. Holtgrieve GW, Schindler DE, Hobbs WO, Leavitt PR, Ward EJ, Bunting L, Chen G, Finney BP, Gregory-Eaves I, Holmgren S, Lisac MJ, Lisi PJ, Nydick K, Rogers LA, Saros JE, Selbie DT, Shapely MD, Walsh PB, Wolfe AP. A coherent signature of anthropogenic nitrogen deposition to 
remote watersheds of the Northern Hemisphere. Science. 2011;6062:1545-8. doi:10.1126/science.1212267.

54. McConnell JR, Aristarain A, Banta J, Edwards P, Simoes J. 20th century doubling in dust archived in an Antarctic Penisula ice core parallels climate change and desertification in South America. PNAS. 2007;104(14):5743-8.

55. Klimont Z, Smith SJ, Cofala J. The last decade of global anthropogenic sulfur dioxide: 2000-2011. Environ Res Lett. 2013;8(1): 14003.

56. Miyazaki K, Eskes H, Sudo K, Boersma KF, Bowman K, Kanaya Y. Decadal changes in global surface NOx emissions from multiconsituent satellite data assimilation. Atmos Chem Phys Discussions. 2016; doi:10.5194/acp-2016-5529.

57. Hilboll A, Richer A, Burrows J. Long-term changes of tropospheric $\mathrm{NO} 2$ over megacities derived from multiple satellite instruments. Atmos Chem Phys. 2013;13:4145-69. doi:10.5194/acp4113-4145-2013.

58.• Paulot F, Jacob D, Pinder R, Bash J, Travis K, Henze D. Ammonia emissions in the United States, European Union, and China derived by the high-resolution inversion of ammonium wet deposition data: interpretation with a new agricultural emissions inventory (MASAGE_NH3). J Geophys Res. 2014;119D:4343-64. doi:10.1002/2013JD021130. Observational based inversion of ammonia emissions, analysis and simulation with a new agricultural emission inventory.

59. Smith SJ, Aardenne Jv, Klimont Z, Andres R, Volke A, Arias SD. Anthropogenic sulfur dioxide emissions: 1850-2005, Atmospheric Chemistry and Physics. 2011;11:1101-1116. doi:10.5194/acp-11-1101-2011.

60. Mouillot F, Narasimha A, Balkanski Y, Lamarque JF, Field C. Global carbon emissions from biomass burning in the 20th century. Geophys Res Lett. 2006;33(L01801) doi:10.1029/2005 GL024707.

61. Marlon J, Bartlein P, Carcaillet C, Gavin D, Harrison S, Higuera P, Joos F, Power M, Prentice IC. Climate and human influences on global biomass burning over the past two millennia. NatureGeosciences. 2008;1:697-701.

62. Kloster S, Mahowald N, Randerson J, Thornton P, Hoffman F, Levis S, Lawrence PJ, Feddema J, Oleson K, Lawrence D. Fire dynamics during the 20th century simulated by the community land model. Biogeosciences. 2010;7:1877-902.

63. Hilboll A, Richter A, Burrows JP. Long-term changes of tropospheric NO2 over megacities derived from multiple satellite instruments. Atmos Chem Phys. 2013:4145-4169. doi:10.5194/acp-4113-4145-2013.

64. Erisman J, Sutton M, Klimont Z, Winiwarter W. How a century of ammonia synthesis changed the world. Nature Geosciences. 2008;1(1):636-9.

65. Hauglustaine D, Balkanski Y, Schultz M. A global model simulation of present and future nitrate aerosols and their radiative forcing of climate. Atmos Chem Phys. 2014;14:11031-63. doi:10.5194/acp-14-11031-2014.

66. Weber R, Guo H, Russel A, Nenes A. High aerosol acidity despite declining atmospheric sulfate concentrations over the past 15 years. Nature-geoscience. 2016;9:282-6. doi:10.1038/ngeo2665.

67. Sutton M, Reis S, Riddick SN, Dragosits U, Nemitz E, Theobald MR, Tang YS, Braban CF, Vieno M, Dore AJ, Mitchell RF, Wanless S, Daunt F, Fowler D, Blackall TD, Milford C, Flechard CR, Loubet B, Massad R, Ellier P, Personne E, Coheur PF, Clarisse L, Van Damme M, Ngadi Y, Clerbaux C, Skjøth CA, Geels C, Hertel O, Wichink Kruit RJ, Pinder RW, Bash JO, Walker JT, Simpson D, Horváth L, Misselbrook TH, Bleeker A, Dentener F, de Vries W. Towards a climate-dependent paradigm of ammonia emission and deposition. Philos Trans R Soc Lond. 2013;B368(1621):20130166. doi:10.1098/rstb.2013.0166.
68. Riddick S, Ward D, Hess PG, Mahowald N, Massad R, Holland E. Estimate of changes in agricultural terrestrial nitrogen pathways and ammonia emissions from 1850 to present in the community earth system model. Biogeosciences. 2016;13:3397-2426.

69. van Vuuren DP, Edmonds J, Kainuma M, Riahi K, Thomson A, Hibbard K, Hurtt G, Kram T, Krey V, Nakicenovic N, Smith S, Rose S. The representative concentration pathways: an overview. Clim Chang. 2011;109:5-31.

70. Ward D, Riddick S, Hess P The impact of changing climate on ammonia emissions from agriculture and the associated climate forcings. In: Fall American Geophysical Union, San Francisco. 2015. p. B13B-0552.

71. Seinfeld J, Pandis S. Atmospheric chemistry and physics. New York: Wiley; 1998.

72. Ansmann A, Seifert P, Tesche M, Wandinger U. Profiling of fine and coarse particle mass: case studies of Saharan dust and Eyjafjallajokull/Grimsvotn volcanic plumes. Atmos Chem Phys. 2012;12:9399-415. doi:10.5194/acp-9312-9399-2012.

73. Neff J, Reynolds MP, Munson S, Fernandez D, Belnap J. The role of dust storms in total atmospheric particle concentration at two sites in the western U.S. J Geophys Res. 2013;118:1-12.

74. Kok J. A scaling theory for the size distribution of emitted dust aerosols suggests climate models underestimate the size of the global dust cycle. Proceedings of the National Academy of Science USA. 2011;108:1016-21.

75. Ryder C, McQuaid J, Flamant C, Rosenberg P, Washington R, Brindley H, Highwood E, Marsham J, Parker D, Todd M, Banks J, Brooke J, Engelstaedter S, Estelles V, Formenti P, GarciaCarreras L, Kocha C, Marenco F, Sodemann H, Allen C, Bourdon A, Bart M, Cavazos-Guerra C, Chevaillier S, Crosier J, Darbyshire E, Dean A, Dorsey J, Kent J, O'Sullivan D, Schepanski K, Szpek K, Trembath J, Wooley A. Advances in understanding mineral dust and boundary layer processes over the Sahara from fennec aircraft observations. Atmos Chem Phys. 2015;15:8479520. doi:10.5194/acp-8415-8479-2015.

76. Ryder C, Highwood E, Lai T, Soderman H, Masham J. Impact of atmospheric transport on the evolution of microphysical and optical properties of Saharan dust. Geophys Res Lett. 2013;40(10): 2433-8. doi:10.1002/grl.50482.

77. Rosenberg P, Parker D, Ryder C, Marsham J, Garcia-Carreras L, Dorsey J, Brooks I, Dean A, Crosier J, McQuaid J, Washington R. Quantifying particle size and turbulent scale dependence of dust flux in the Sahara using air craft measurements. J Geophys Res. 2014;119:7577-98. doi:10.1002/2013JD021255.

78. Reid JS, Jonson H, Maring H, Smirnov A, Savoie D, Cliff S, Reid E, Livingston J, Meier M, Dubovik O, Tsay S-C. Comparison of size and morphological measurements of dust particles from Africa. J Geophys Res. 2003;108(D19):8593. doi:10.1029/2002 JD002485.

79. Maring J, Savoie D, Izaguirre M, Custals L, Reid J. Mineral dust aerosol size distribution change during atmospheric transport. J Geophys Res. 2003;108(D19):8592.

80. Lawrence CR, Neff J. The contemporary physical and chemical flux of Aeolian dust: a synthesis of direct measurements of dust deposition. Chem Geol. 2009;257:46-63.

81. Mahowald N, Albani S, Kok J, Engelstaedter S, Scanza R, Ward DS, Flanner M. The size distribution of desert dust aerosols and its impact on the Earth system. Aeolian Res. 2014;15:53-71. doi:10.1016/j.aeolia.2013.1009.1002.

82. Albani S, Mahowald N, Perry A, Scanza R, Zender C, Flanner MG. Improved representation of dust size and optics in the CESM. J Adv Model Earth Syst. 2014;6. doi:10.1002/2013MS000279.

83. Schulz M, Balkanski Y, Guelle W, Dulac F, Moulin C, Lambert CE. Model components necessary to capture a dust plume pattern over the Mediterranean Sea. In: Guerzoni S, Chester R, editors. 
The impact of desert dust across the Mediterranean. Dordrecht: Kluwer Academic Publishers; 1996. p. 51-8.

84. Guieu C, Bonnet S, Wagener T, Loye-Pilot M-D. Biomass burning as a source of dissolved iron to the open ocean? Geophys Res Lett. 2005;22:L19608. doi:10.1029/2005GL022962.

85. Chuang P, Duvall R, Shafer M, Schauer J. The origin of water soluble particulate iron in the Asian atmospheric outflow. Geophys Res Lett. 2005;32(L07813) doi:10.1029/2004 GL021946.

86. Herut B, Krom M, Pan G, Mortimer R. Atmospheric input of nitrogen and phosphorus to the Southeast Mediterranean: sources, fluxes and possible impact. Limnol Oceanogr. 1999;44(7):168392.

87. Boy J, Rollenbeck R, Valarezo C, Wilcke W. Amazonian biomass burning-derived acid and nutrient deposition in the north Andean montane forest of Ecuador. Glob Biogeochem Cycles. 2008;22: GB4011. doi:10.1029/2007GB3158.

88. Benitez-Nelson C, Vink S, Carrillo J, Huebert B. Volcanically influenced iron and aluminum cloud water deposition to Hawaii. Atmos Environ. 2003;37:535-44.

89. Galloway J, Likens G, Keene WC, Miller J. The composition of precipitation in remote areas of the world. J Geophys Res. 1982;87(C11):8771-86.

90. Graham B, Guyon P, Maenhaut W, Taylor PE, Ebert M, MatthiasMaser S, Mayol-Bracero OL, Godoi RHM, Artaxo P, Meixner FX, Moura MAL, Rocha CHE, VanGrieken R, Globsky MM, Flagan $\mathrm{RC}$, Andreae MO. Composition and diurnal variability of the natural Amazonian aerosol. J Geophys Res. 2003;108(D24):4765. doi:10.1029/2003JD004049.

91. Mahowald N, Baker A, Bergametti G, Brooks N, Duce R, Jickells T, Kubilay N, Prospero J, Tegen I. The atmospheric global dust cycle and iron inputs to the ocean. Glob Biogeochem Cycles. 2005;19(4):GB4025. doi:10.1029/2004GB002402.

92. $\mathrm{Fu} \mathrm{W}$, Randerson J, Moore JK. Climate change impacts on net primary production (NPP) and export production (EP) regulated by increasing stratification and phytoplankton community structure in the CMIP5 models. Biogeosciences in press. 2016.

93. Baker A, Croot P. Atmospheric and marine controls on aerosol iron solubility in seawater. Mar Chem. 2010;120:4-13.

94. Sholkovitz E, Sedwick P, Church T, Baker A, Powell C. Fractional solubility of aerosol iron: synthesis of a global-scale data set. Geochim Cosmochim Acta. 2012;89:173-89.

95. Claquin T, Schulz M, Balkanski Y. Modeling the mineralogy of atmospheric dust sources. J Geophys Res. 1999;104(D18):22, 243-222,256.

96. Nickovic S, Vukovic A, Vujadinovic M, Djurdjevic V, Pejanovic G. Technical note: high-resolution mineralogical database of dustproductive soils for atmospheric dust modeling. Atmos Chem Phys. 2012;12:845-55. doi:10.5194/acp-5112-5845-2012.

97. Journet E, Balkanski Y, Harrison S. A new data set of soil mineralogy for dust-cycle modeling. Atmos Chem Phys. 2014;14: 3801-16. doi:10.5194/acp-3814-3801-2014.

98. Perlwitz J, Perez C, Miller R. Predicting the mineral composition of dust aerosols - part 1: representing key processes. Atmos Chem Phys. 2015;15:11593-627. doi:10.5194/acp-15-11593-2015.

99. Perlwitz J, Perez C, Miller R. Predicting the mineral composition of dust aerosols - part 2: model evaluation and identification of key processes with observations. Atmospheric Chemistry and Physics Discussions. 2015;15:11629-52. doi:10.5194/acp-1511629-2015.

100. Scanza R, Mahowald N, Ghan S, Zender C, Kok J, Liu X, Zhang Y. Dependence of dust radiative forcing on mienralogy in the community atmosphere model. Atmos Chem Phys. 2015;15: 537-61.

101. Zhang Y, Mahowald N, Scanza R, Journet E, Desboefs K, Albani S, Zhuang G, Chen Y, Cohen D, Paytan A, Patey M, Achterberg E,
Engelbecht J, Fomba K. Modeling the global emission, transport and deposition of trace elements associated with mineral dust. Biogeosciences. 2015;12:5771-92. doi:10.5194/bg-5712-57712015.

102. Journet E, Desbouefs K, Caqineau S, Colin J-L. Mineralogy as a critical factor of dust iron solubility. Geophys Res Lett. 2008;35(L07805) doi:10.1029/2007GL031589.

103. Schroth A, Crusius J, Sholkovitz E, Bostick B. Iron solubility driven by speciation in dust sources to the ocean. Nature-geoscience. 2009;2:337-40. doi:10.1038/ngeo1501.

104. Shi Z, Krom M, Jickells T, Bonneville S, Carslaw KS, Mihalopoulos N, Baker A, Benning L. Impacts on iron solubility in the mneral dust by processes in the source region and in the atmosphere: a review. Aeolian Res. 2012;5:21-42.

105. Schulz M, Prospero J, Baker A, Dentener F, Ickes L, Liss P, Mahowald N, Nickovic S, Perez C, Rodriguez S, Sarin M, Tegen I, Duce R. The atmospheric transport and deposition of mineral aerosols to the ocean: implications for reseach needs. Environ Sci Technol. 2012;46:10390-404. doi:10.1021/es300073u.

106.• Jickells T, Moore CM. The importance of atmospheric deposition for ocean productivity. Ann Rev Ecol Evol Syst. 2015;46:481501. Review of the role of atmospheric deposition to the oceans.

107. Zhu X, Prospero J, Millero F. Diel variability of soluble Fe(II) and soluble total $\mathrm{Fe}$ in North Africa dust in the trade winds at Barbados. J Geophys Res. 1997;102(7):21297-305.

108. Meskhidze N, Chameides W, Nenes A. Dust and pollution: a recipe for enhanced ocean fertilization? J Geophys Res. 2005;110(D03301) doi:10.1029/2004JD005082.

109. Paris R, Desboefs K, Journet E. Variability of dust iron solubilty in atmospheric wters: investigation of the role of oxalate organic complexation. Atmospheric Enviroment. 2011;45:6510-7.

110. Johnson M, Meskhidze N. Atmospheric dissolved iron deposition to the global oceans: effects of oxalate-promoted Fe dissolution, photochemical redo cycling and dust mineralogy. Geosci Model Dev. 2013;6:1137-55. doi:10.5194/gmd-1136-1137-2013.

111. Ito A, Shi Z. Delivery of anthropogenic bioavailable iron from mineral dust and combustion aerosol to the ocean. Atmos Chem Phys. 2016;16:85-99. doi:10.5194/acp-5116-5185-2016.

112. Sedwick P, Sholkovitz E, Church T. Impact of anthropogenic combustion emissions on the fractional solubility of aerosol iron: evidence from the Sargasso Sea. Geochemistry, Geophysics and Geosystems. 2007;8(Q10Q06) doi:10.1029/2007GC001586.

113. Ito A. Atmospheric processing of combustion aerosols as a source of bioavailable iron. Environmental Science and Technology Letters. 2015;2:70-5.

114. Baker A, Laskina O, Grassian V. Processing and ageing in the atmosphere. In: Knippertz P, Stutt J-B, editors. Mineral dust: a key player in the Earth system. Dordrecht: Springer Science+ Business Media; 2014. p. 75-92. doi:10.1007/978-94-017-897834.

115. Longo A, Feng Y, Lai B, Landing W, Shelley R, Nenes A, Mihalopoulos N, Violaki K, Ingall E. Influence of atmospheric processes on the solubility and composition of iron in Saharan dust. Environmental Science and Technology in press. 2016; doi:10.1021/acs.est.1026b02605.

116. Zender C, Miller R, Tegen I. Quantifying mineral dust mass budgets: terminology, constraints and current estimates. EOS. 2004;85(48):509-12.

117. Winton W, Bowie A, Keywood M, Townsend A, van der Merwe P, Bollhofer A. Fractional iron solubility of atmospheric iron inputs to the Southern Ocean. Mar Chem. 2015;177:20-32.

118. Heimburger A, Losno R, Triquet S. Solubility of iron and other trace elements in rainwater collected on the Kerguelen Islands (South Indian Ocean). Biogeosciences. 2013;10:6617-28. 
119. Mulitza S, Heslop D, Pittauerova D, Fischer H, Meyer I, Stuut J-B, Zabel M, Mollenhauer G, Collins J, Kuhnert H, Schulz M. Increase in African dust flux at the onset of commercial agriculture in the Sahel region. Nature. 2010;466:09226-8. doi:10.1038/nature09213.

120. Ginoux P, Prospero J, Gill TE, Hsu NC, Zhao M. Global scale attribution of anthropogenic and natural dust sources and their emission rates based on MODIS deep blue aerosol products. Rev Geophys. 2012;50(RG3005) doi:10.1029/2012RG000388.

121. Tegen I, Werner M, Harrison SP, Kohfeld KE. Relative importance of climate and land use in determining present and future global soil dust emission. Geophys Res Lett. 2004;31:L05105. doi:10.1029/2003GL019216. 012004

122. Ward DS, Mahowald N, Kloster S. Potential climate forcing of land use and land cover change. Atmos Chem Phys. 2014;14: 12701-24.

123. Woodward S, Roberts D, Betts R. A simulation of the effect of climate changed-induced desertification on mineral dust aerosol. Geophys Res Lett. 2005;32:L18810. doi:10.1029/2005 GL023482.

124. Evan A, Flamant C, Gaetani M, Guichard F. The past, present and future of African dust. Nature. 2016;531:493-5.

125. Tipping E, Benham S, Boyle J, Crow P, Davies J, Fischer U, Guyatt H, Helliwell R, Jackson-Blake L, Lawlor A, Montheith D, Rowe E, Toberman H. Atmospheric deposition of phosphorus to land and freshwater. Environmental Science Processes Impacts. 2014;16:1608-17.

126. Huffman J, Sinha B, Garland R, Snee-Pollman A, Gunthe S, Artaxo P, Martin S, Andreae M, Poschl U. Size distributions and temporal variations o biological aerosol particles in the Amazon rainforest characterized by microscopy and real time UV-APs fluoresence techniques during AMAZE-08. Atmos Chem Phys. 2012;12:11997-2019. doi:10.15194/acp-11912-11197-12012.

127. Pachauri T, Singla V, Satsangi A, Lakhani K, Kumari M. SEM-EDX characterization of individual coarse particles in Agra, India. Aerosol Air Qual Res. 2013;13:523-36. doi:10.4209/aaqr.2012.4204.0095.

128. Despres V, Huffman J, Burrows SM, Hoose C, Safatov A, Buryak G, Frohlich-Nowoisky J, Elbert W, Andreae M, Polsch U, Jaenicke R. Primary biological aerosol particles in the atmosphere: a review. Tellus B. 2012;64(15598) doi:10.3402/tellusb.v3464 i3400.15598.

129. Wang R, Balkanski Y, Boucher O, Ciais P, Penuelas J, Tao S. Significant contribution of combustion-related emissions to the atmospheric phosphorus budget. Nat Geosci. 2015;8:48-54.

130. Baker A, French M, Linge K. Trends in aerosol nutrient solubility along a west-east transect of the Saharan dust plume. Geophys Res Lett. 2006;33(L07805) doi:10.1029/2005GL024764.

131. Nenes A, Krom M, Mihalopoulos N, VanCapellen P, Shi Z, Bougiatioti A, Zarmpas P, Herut B. Atmospheric acidification of mineral aerosols: a source of bioavailable phosphorus to the oceans. Atmos Chem Phys. 2011;11:6265-72. doi:10.5194/acp6211-6265-2011.

132. Myriokefalitakis S, Nenes A, Baker A, Mihalopoulos N, Kanakidou M. Bioavailable atmospheric phosphorus supply to the global ocean: a 3-d global modeling study. Biogeosciences Discussion. 2016; doi:10.5194/bg-2016-5215.

133. Nriagu J, Pacyna J. Quantitative assessment of worldwide contamination of air, water and soils by trace metals. Nature. 1988;333: 134-9.

134. Psenner R. Living in a dusty world: airborne dust as a key factor for alpine lakes. Water Air Soil Pollut. 1999;112(3):217-27.

135. Magnani F, Mencuccini M, Borghetti M, Bergigier P, Berninger F, Delzon S, Grelle A, Hari P, Jarvis P, Kolari P, Kowalski A, Lankreijer H, Law B, Lindroth A, Loustau D, Manca G, Moncrieff J, Rayment M, Tedeschi V, Valentini R, Grace J. The human footprint in the carbon cycle of temperate and boral forests. Nature. 2007;447:848-51.

136. Thornton P, Doney S, Lindsay K, Moore JK, Mahowald N, Randerson J, Fung I, Lamarque JF, Feddema J, Lee Y-H. Carbon-nitrogen interactions regular climate-carbon cycle feedbacks: results from an atmosphere-ocean general circulation model. Biogeosciences. 2009;6:2099-120. doi:10.5194/bg-20952099-2009.

137. Zaehle S, Friend A, Friedlingstein P, Dentener F, Peylin P, Schulz $\mathrm{M}$. Carbon and nitrogen dynamics in the $\mathrm{O}-\mathrm{CN}$ land surface model: 2. Role of the nitrogen cycle in the historical terrestrial carbon balance. Glob Biogeochem Cycles. 2010;24(GB1006) doi:10.1029/2009GB003522.

138.• Janssens IA, Dielemann W, Lyssaert S, Subke J-A, Reichstein M, Ceulemans R, Ciais P, Dolman A, Grace J, Matteucci G, Paple D, Piao S, Schulze E-D, Tang J, Law B. Reduction of forest soil respiration in response to nitrogen deposition. Nat Geosci. 2010;3:315-22. doi: 10.1038/ngeo1844 . A meta-analysis of observations shows the response of soil respiration to nitrogen deposition.

139. Liu L, Greaver T. A global perspective on belowground carbon dynamics under nitrogen enrichment. Ecol Lett. 2010;13: 8190828. doi:10.1111/j.1461-0248.2010.01482.x.

140. Frey S, Ollinger S, Nadelhoffer K, Bowden R, Brzostek E, Burton A, Caldwell B, Crow S, Goodale C, Grandy A, Finzi A, Kramer M, Lajtha K, LeMoine J, Martin M, McDowell W, Minocha R, Sadowsky J, Templer P, Wickings K. Chronic nitrogen additions suppress decomposition and sequester soil carbon in temperate forests. Biogeochemistry. 2014;121:305-16. doi:10.1007/s1053310014-10004-10530. Argues that increased nitrogen deposition suppresses soil decomposition.

141. Liu L, Greaver T. A review of nitrogen enrichment effects on three biogenic GHGs: the $\mathrm{CO} 2$ sink may be largely offset by stimulated N2O and CH4 emission. Ecol Lett. 2009;12:1-12. doi:10.1111 /j.1461-0248.2009.01351.x.

142. Butterbach-Bahl K, Nemitz E, Zaehle S, Billen G, Boeckx P, Erisman J, Garnier J, Upstill-Goddard R, Kreuzer M, Oenema O, Reis S, Schaap M, Simpson D, deVries W, Winiwarter W, Sutton M. Chapter 19: nitrogen as a threat to the European greenhouse balance. In: Sutton MA, Howard CM, Erisman JW, Billen G, Bleeker A, Grennfelt P, van Grinsven H, Grizzetti B, editors. The European nitrogen assesment. Cambridge: Cambridge University Press; 2011. p. 434-62.

143. Pinder R, Davidson E, Goodale C, Greaver T, Herrick J, Liu L. Climate change impacts of US reactive nitrogen. PNAS. 2012;109(20):7671-51. doi:10.1073/pnas.1114243109.

144. Driscoll CT, Lawrence G, Bulger A, Butler T, Cronan C, Eager C, Lambert K, Likens G, Stoddard J, Weathers K. Acidic deposition in the northeastern United States: sources and inputs, ecosystem effects and management strategies. Bioscience. 2001;51(3):180 98.

145. Battles J, Fahey T, Driscoll CT, Blum J, Johnson CE. Restoring soil calcium reverses forest decline. Environmental Science and Technology Letters. 2013;1:15-9. doi:10.1021/ez400033d.

146. Oulehle F, Evans C, Hofmeister J, Krejci R, Tahovska K, Persson $\mathrm{T}$, Cudlin P, Hruska J. Major changes in forest carbon and nitrogen cycling caused by declining sulphur deposition. Glob Chang Biol. 2011;17:3115-29. doi:10.1111/j.1365-2486.2011.02468.x.

147. Monteith DT, Stoddard JL, Evans CD, de Wit HA, Forsius M, Hogasen T, Wilander A, Skjelkvale BL, Jeffries DS, Vuorenmaa J, Keller B, Kopacek J, Vesely J. Dissolved organic carbon trends resulting from changes in atmospheric deposition chemistry. Nature. 2007;450(7169):537-40. doi:http://www.nature. com/nature/journal/v450/n7169/suppinfo/nature06316 S1.html 
148. Evans CD, Jones TG, Burden A, Ostle N, Zielinski P, Cooper MDA, Peacock M, Clark JM, Oulehle F, Cooper D, Freeman C. Acidity controls on dissolved organic carbon mobility in organic soils. Glob Chang Biol. 2012;18:3317-31.

149. Gauci V, Matthews E, Dise N, Walter B, Koch D, Granberg G. Sulfur polution suppression of the wetland methane source in the 20th and 21st centuries. PNAS. 2004;101(34):12583-7.

150. Townsend A, Cleveland C, Houlton B, Alden C, White J. Multi-element regulartion of the tropical forest carbon cycle. Frontiers of Ecology and the Environment. 2011;9(1): 9-17. doi:10.1890/100047.

151. Okin G, Mahowald N, Chadwick O, Artaxo P. The impact of desert dust on the biogeochemistry of phosphorus in terrestrial ecosystems. Glob Biogeochem Cycles. 2004;18:GB2005. doi:10.1029/2003GB002145.

152. Rizzolo J, Barbosa C, Brorillo G, Godoi A, Souza R, Andreoli R, Manzi A, Sa M, Alves E, Pohlker C, Angelis I, Ditas F, Saturno J, Moran-Zulaoaga D, Rizzo L, Rosario N, Pauliquevis T, Yamamoto C, Andreae M, Taylor PE, Godoi R. Mineral nutrients in Saharan dust and their potential impact on Amazon rainforest ecology. Atmospheric Chemistry and Physics Discussions. 2016; doi:10.5194/acp-2016-557.

153. Parton WJ, Neff JC, Vitousek PM. Modeling phosphorus dynamics in terrestrial ecosystems. In: Turner BL, Frossard E, Lindau ETH, Baldwin DS, editors. Organic phosphorus and the environment. London: Oxford University Press; 2005. p. 325-47.

154. Chadwick OA, Derry LA, Vitousek PM, Huebert BJ, Hedin LO. Changing sources of nutrients during four million years of ecosystem development. Nature. 1999;397:491-6.

155. Avila A, Alarcon M, Queralt I. The chemical composition of dust transported in red rains - its contribution to the biogeochemical cycle of a holm oak forest in Catalonia (Spain). Atmos Environ. 1998;32(2):179-91.

156. Riskin S, Porder S, Neill C, Figueria AMS, Tubbesing C, Mahowald N. The fate of phosphorus fertilizer in Amazon soya bean fields. Philos Trans R Soc B. 2013;368(so120154) doi:10.1098/rstb.2012.0154.

157. Houlton B, Wang Y-P, Vitousek P, Field C. A unifying framework for dinitrogen fixation in the terrestrial biosphere. Nature. 2008;454:327-31. doi:10.1038/nature07028.

158. Wang YP, Law R, Pak B. A global model of carbon, nitrogen and phosphorus cycles for the terrestrial biosphere. Biogeosciences. 2010;7:2261-82.

159. Baron J, Driscoll CT, Stoddard J, Richer E. Empirical critical loads of atmospheric nitrogen deposition for nutrient enrichment and acidification of sensitive US lakes. Bioscience. 2011;61(8):60213.

160. Morales-Baquero R, Pulido-Villena E, Reche I. Atmospheric inputs of phosphorus and nitrogen to the southwest Mediterranean region: biogeochemical responses of high mountain lakes. Limnology and Oceangraphy. 2006;51(2):830-7.

161. Wolfe AP, Baron J, Cornett J. Anthropogenic nitrogen deposition induces rapid ecological changes in alpine lakes of the Colorado Front Range (USA). J Paleolimnol. 2001;25:1-7.

162. Brahney J, Ballantyne A, Kociolek P, Leavitt PR, Farmer GL, Neff J. Ecological changes in two contrasting lakes associated with human activity and dust transport in western Wyoming. Limnology and Oceangraphy. 2015;6(2):678-95.

163. Hanson P, Pollard A, Bade D, Predick K, Carpenter S, Foley J. A model of carbon evasion and sedimentation in temperate lakes. Glob Chang Biol. 2004;10:1285-98. doi:10.1111/j.13652486.2004.00805.x.

164. Downing J, Cole J, Middelburg J, Striegl R, Duarte C, Kortelainen $\mathrm{P}$, Prairie Y, Laube K. Sediment organic carbon burial in agriculturally eutrophic impoundments over the last century. Glob
Biogeochem Cycles. 2008;22(GB1018) doi:10.1029/2006 GB002854.

165. Alin S, Johnson T. Carbon cycling in large lakes of the world: a synthesis of production, burial and lake-atmosphere exchange estimates. Glob Biogeochem Cycles. 2007;21(GB3002) doi:10.1029/2006GB002881.

166. Algesten G, Sobek S, Bergstrom A-K, Gren A, Tranvik L, Jansson M. Role of lakes for organic carbon cycling the boreal zone. Glob Chang Biol. 2003;10:141-7. doi:10.1046/j.15298817.2003.00721.x.

167. Cole J, Prairie Y, Caraco N, McDowell W, Tranvik L, Striegl R, Duarte C, Kortelainen P, Downing J, Middelburg J, Melack J. Plumbing the global carbon cycle: integrating inland waters into the terrestrial carbon budget. Ecosystems. 2007;10:171-84. doi:10.1007/s10021-10006-19013-10028.

168. Dean W, Gorham E. Magnitude and significance of carbon burial in lakes, reservoirs and peatlands. Geology. 1998;26(6):535-8.

169. Tranvik L, Downing J, Cotner J, Loiselle S, Striegl R, Ballatore T, Dillon P, Finlay K, Fortino K, Knoll L, Kortelainen P, Kutser T, Larsen S, Laurion I, Leech D, McCallister S, McKnight D, Melack J, Overholt E, Porter J, Prairie Y, Renwick W, Roland R, Sherman B, Schindler DE, Sobek S, Tremblay A, Vanni M, Verschoor A, von Wachenfeldt E, Weyhenmeyer G. Lakes and reservoirs as regulators of carbon cycling and climate. Limnology and Oceangraphy. 2009;54(6, part 2):2298-314.

170. Moore JK, Lindsay K, Doney S, Long M, Misumi K. Marine ecosystem dynamics and biogeochemical cycling in the community Earth System Model1 (BGC): comparison of the 1990s with the 2090s under the RCP4.5 and RCP8.5 scenarios. J Clim. 2013;26(23):9291-312. doi:10.1175/jcli-d-9212-00566.00561.

171. Ito A, Nenes A, Johnson CE, Meskhidze N, Deutsch C. Acceleration of oxygen decline in the torpical Pacific over the past decades by aerosol pollutants. Nat Geosci. 2016;9:443-8. doi:10.1038/ngeo2717.

172. Wang R, Balkanski Y, Bopp L, Aumont O, Boucher O, Ciais P, Gehlen M, Penuelas J, Ethé C, Hauglustaine D, Li B, Liu J, Zhou $\mathrm{F}$, Tao S. Influence of anthropogenic aerosol deposition on the relationship between oceanic productivity and warming. Geophys Res Lett. 2015;42(10):745-710,754. doi:10.1002/2015 GL066753.

173. Krishnamurthy A, Moore JK, Mahowald N, Luo C, Zender CS. The impacts of atmospheric nutrient inputs on marine biogeochemistry. J Geophys Res. 2010;115(G01006) doi:10.1029/2009 JG001115.

174. Okin G, Baker A, Tegen I, Mahowald N, Dentener F, Duce R, Galloway J, Hunter K, Kanakidou M, Kubilay N, Prospero J, Sarin M, Surpipith V, Uematsu M, Zhu T. Impacts of atmospheric nutrient deposition on marine productivity: roles of nitrogen, phosphorus and iron. Glob Biogeochem Cycles. 2011;25(GB2022) doi:10.1029/2010GB003858.

175. Moore C, Mills M, Arrigo K, Berman-Frank I, Bopp L, Boyd P, Galbraith E, Geider R, Guieu C, Jaccard S, Jickells T, LaRoche J, Lenton T, Mahowald N, Maranon E, Marinov I, Moore JK, Nakatuka T, Oschilies A, Saito M, Thingstad T, Tsuda A, Ulloa O. Processes and patterns of oceanic nutrient limitation. Nat Geosci. 2013;6:701-10. doi:10.1038/NGEO1765. Data/model synthesis paper that focuses on nutrient impacts on ocean biogeochemistry.

176. Moon J-Y, Lee K, Tanhua T, Kress N, Kim I-N. Temporal nutrient dynamics in the Medtierranean Sea in response to anthropogenic inputs. Geophys Res Lett. 2016;43 doi:10.1002/2016GL068788.

177. Powley H, Krom M, Emeis K-C, Cappellen V. A biogeochemical model for phosphorus and nitrogen cycling in the Eastern Mediterranean Sea: part 2. Response of nutrient cycles and 
primary production to anthropogenic forcing: 1950-2000. J Mar Syst. 2014;139:420-32. doi:10.1016/jmarsys.2014.1008.1017.

178. Guieu C, Aumont O, Paytan A, Bopp L, Law C, Mahowald N, Achterberg E, Maranon E, Salihoglu B, Crise A, Wagener T, Herut B, Desboeufs K, Kanakidou M, Olgun N, Peters F, Pulido-Villena E, Tovar-Sanches A, Volker C. The significance of the episodic nature of atmospheric deposition to the low nutrient low chlorophyll regimes. Glob Biogeochem Cycles. 2014;38:1179-98. doi:10.1002/2014GB004852.

179. Tagliabue A, Aumont O, Bopp L. The impact of different external sources of iron on the global carbon cycle. Geophys Res Lett. 2014;41(3):920-6. doi:10.1002/2013g1059050.

180. Tagliabue A, Aumont O, DeAth R, Dunne J, Dutkiewicz S, Galbraith E, Misumi K, Moore K, Ridwell A, Sherman E, Stock C, Vichi M, Volker C, Yool A. How well do global ocean biogeochemistry models imulate dissolved iron distributions? Glob Biogeochem Cycles. 2016;30:149-74. doi:10.1002/2015 GB005289. Model intercomparison of iron cycling in ocean model, highlighting large uncertainties in treatment and resulting distributions.

181. Jickells T, Boyd P, Hunter K. Biogeochemical impacts of dust on the global carbon cycle. In: Knippertz P, Stutt J-B, editors. Mineral dust: a key player in the earth system. Dordrecht: Springer Science+ Business Media; 2014. p. 359-284.

182. Rijkenberg M, Middag R, Laan P, Gerringa L, van Aken H, Shoemann V, deJong J, de Baar H. The distribution of dissolved iron in the West Atlantic Ocean. PLoS One. 2014;9(6):1-14. Meridional GEOTRACES section through the entire
Atlantic basin documents a short residence time for iron in the oceans, illustrating the dominance of regional-scale sources and sinks.

183. Buck K, Bohst B, Sedwick P. The organic complexation of dissolved iron along the U.S. GEOTRACES (GA03) North Atlantic Section. Deep-Sea Research II. 2015;116:152-65.

184. Mahaffey C, Reynold S, Davis C, Lohan M. Alkaline phosphatase activity in the subtropical ocean: insights from nutrient, dust and trace metal addition experiments. Front Mar Sci. 2014;1:1-13. doi:10.3389/fmars.2014.00073.

185. Martiny A, Pham C, Primeau F, Vrugt J, Moore JK, Levin S, Lomas M. Strong latitudinal patterns in the elemental ratios of marine plankton and organic matter. Nat Geosci. 2013;6(4):279 83. doi:10.1039/ngeo1757.

186. Teng Y-C, Primeau F, Moore JK, Lomas M, Martiny A. Globalscale variations of the ratios of carbon to phosphorus in exported marine organic matter. Nat Geosci. 2014;7:895-8.

187. Singh A, Lomas M, Bates N. Revisiting N2 fixation in the North Atlantic Ocean: significance of deviations from the Redfield ratio, atmospheric deposition and climate variability. Deep-Sea Research II. 2013;93:148-58.

188. Ratten J, LaRoche J, Desai D, Shelley R, Landing W, Boyle E, Cutter GA, Langlois R. Source of iron and phosphate affect the distribution of diazotrophs in the North Atlantic. Deep-Sea Research II. 2015;116(332-341)

189. Cui DY, Wang JT, Tan LJ, Dong ZY. Impact of atmospheric wet deposition on phytoplankton community structure in the South China Sea. Estuar Coast Shelf Sci. 2016;173:1-8. 